\title{
Ceramide Transfer Protein (CERT): An Overlooked Molecular Player in Cancer
}

\author{
Long Hoa Chung *, Da Liu (D), Xin Tracy Liu (D) and Yanfei Qi *(1) \\ Centenary Institute of Cancer Medicine and Cell Biology, University of Sydney, \\ Camperdown, NSW 2050, Australia; darren.liu@centenary.org.au (D.L.); x.liu@centenary.org.au (X.T.L.) \\ * Correspondence: 1.chung@centenary.org.au (L.H.C.); j.qi@centenary.org.au (Y.Q.); \\ Tel.: +61-(043)-003-3263 (L.H.C.); +61-(286)-276-045 (Y.Q.)
}

check for updates

Citation: Chung, L.H.; Liu, D.; Liu, X.T.; Qi, Y. Ceramide Transfer Protein (CERT): An Overlooked Molecular Player in Cancer. Int. J. Mol. Sci. 2021, 22, 13184. https://doi.org/10.3390/ ijms222413184

Academic Editor: Dimitrios J. Stravopodis

Received: 12 November 2021 Accepted: 5 December 2021 Published: 7 December 2021

Publisher's Note: MDPI stays neutral with regard to jurisdictional claims in published maps and institutional affiliations.

Copyright: (c) 2021 by the authors. Licensee MDPI, Basel, Switzerland. This article is an open access article distributed under the terms and conditions of the Creative Commons Attribution (CC BY) license (https:// creativecommons.org/licenses/by/ $4.0 /)$.

\begin{abstract}
Sphingolipids are a class of essential lipids implicated in constructing cellular membranes and regulating nearly all cellular functions. Sphingolipid metabolic network is centered with the ceramide-sphingomyelin axis. Ceramide is well-recognized as a pro-apoptotic signal; while sphingomyelin, as the most abundant type of sphingolipids, is required for cell growth. Therefore, the balance between these two sphingolipids can be critical for cancer cell survival and functioning. Ceramide transfer protein (CERT) dictates the ratio of ceramide to sphingomyelin within the cell. It is the only lipid transfer protein that specifically delivers ceramide from the endoplasmic reticulum to the Golgi apparatus, where ceramide serves as the substrate for sphingomyelin synthesis. In the past two decades, an increasing body of evidence has suggested a critical role of CERT in cancer, but much more intensive efforts are required to draw a definite conclusion. Herein, we review all research findings of CERT, focusing on its molecular structure, cellular functions and implications in cancer. This comprehensive review of CERT will help to better understand the molecular mechanism of cancer and inspire to identify novel druggable targets.
\end{abstract}

Keywords: CERT; ceramide; sphingomyelin; sphingolipid; lipid transfer protein; lipidomics; cancer

\section{Introduction}

Cancer cells exhibit altered lipid profile and metabolism, enabling them to meet the bioenergetic, biochemical and biophysical requirements for cancer initiation, progression and metastasis [1,2]. Within cancer cell, lipids can serve as a form of stored energy, membrane constituents and signaling molecules [3]. Meanwhile, the circulating lipids represent dietary nutrient intake and impacts, regulate hormonal and immunological responses and convey interorgan communications in cancer [4,5]. With the development of high throughput lipidomics and mass-spectrometry-based lipid imaging, an exponentially increased number of cancer-related lipid changes have been identified in cancer cells, animal models and clinical cohorts [6-9]. These often uncover previously overlooked lipid species in cancer, which offer new avenues for cancer diagnosis and treatment $[6,8]$.

Lipid metabolites are categorized into eight well-defined groups under the guidance of the International Lipid Classification and Nomenclature Committee. It includes fatty acyls, glycerolipids, glycerophospholipids, sphingolipids, sterol lipids, prenol lipids, saccharolipids and polyketides [10]. Among them, sphingolipids are a class of critical molecular players in cancer: sphingomyelin, ceramide and glycosphingolipids serve as structural lipids in the cellular membrane, where they form sphingolipid-enriched microdomains and regulate cancer cell signaling [11,12]; while ceramide, sphingosine and sphingosine 1-phosphate (S1P) can directly function as signaling molecules implicated in cancer cell proliferation, metabolism and death, inflammation, tumor angiogenesis, metastasis and drug resistance [13-18]. Notably, ceramide has been recognized as a tumor-suppressive factor in most cancer types $[19,20]$. In contrast, sphingomyelin is considered essential for cancer cell proliferation, migration and immune evasion $[21,22]$. Therefore, the ratio of ceramide 
to sphingomyelin might determine the outcomes of cancer development. Supporting this notion, sphingomyelinases that hydrolyze sphingomyelin to ceramide suppress cancers and improve anti-cancer therapies [23-27], whereas sphingomyelin synthases that convert ceramide to sphingomyelin promote cancers [28-32].

In addition to sphingomyelinases and sphingomyelin synthases, ceramide transfer protein (CERT), also known as goodpasture antigen-binding protein (GPBP), collagen type IV alpha-3-binding protein (COL4A3BP) or StAR-related lipid transfer protein 11 (STARD11), is another key factor in regulating ceramide/sphingomyelin ratio. CERT is the only lipid transfer protein known to transport ceramide from the endoplasmic reticulum (ER) to the trans-Golgi apparatus, a prerequisite step for converting ceramide into sphingomyelin $[33,34]$. Since the identification of its ceramide transport function, the role of CERT in cancer has been continually studied; however, the latest review specifically on this research topic dates back to 10 years ago [35]. With the development of lipidomic analyses and the advancement of structural biology, have we obtained any new knowledge on CERT in the past decade? This article intends to provide a comprehensive review on CERT with focuses on its molecular structure, cellular functions and implications in cancer.

\section{Sphingolipid Metabolism Centered with Ceramide/Sphingomyelin Axis}

\subsection{Chemical Structure of Sphingolipids}

Sphingolipids are one of the major lipid classes in eukaryotes. These lipids build on a common backbone of an aliphatic amino alcohol, referred to as the sphingoid base [36,37]. The sphingoid base was first identified in 1884 by a German chemist J.L.W Thudichum who named this structure for its enigma as the Egyptian Sphinx [38]. The sphingoid base contains one to three hydroxyl groups, designated as " $\mathrm{m}$ ", " $\mathrm{d}$ " or " $\mathrm{t}$ " for mono-, di- and trihydroxy groups, respectively [39]. In addition, the sphingoid base can be saturated, monounsaturated or di-unsaturated (with double bonds in either cis- or trans-configuration) [39]. The most common sphingoid base is sphingosine which was first elucidated by H.E Carter et al. in 1947 [40]. On the sphingoid base, the addition of fatty acyl chain in different lengths (C14-C28) via N-link bond and the attachment of choline, phosphate or sugar molecules via O-link bond leads to the biodiversity of sphingolipids [36,37]. The chemical structure of major sphingolipids, including sphingosine, dihydrosphingosine (dh-sphingosine), S1P, ceramide, sphingomyelin and glycosylceramide, are listed in Figure 1. A shorthand nomenclature is currently used to denote sphingolipids (detailed in [39]). For example, sphingosine contains 18-carbon (C18) with two hydroxyl groups and one trans-double bond at its $\mathrm{C} 4$ position, and thus it is denoted as $4 \mathrm{E}-\mathrm{d} 18: 1$; while ceramide that possesses a fatty acyl chain in 16-carbon length via the $\mathrm{N}$-link to the sphingoid base is abbreviated as C18:1/C16:0 or C16:0 in short [39]. So far, 1748 curated and 3168 computationally generated sphingolipid species have been characterized [41,42]. Among these sphingolipids, ceramide is sitting at the central point of the de novo biosynthetic and catabolic pathways in the sphingolipid metabolic network (Figure 2). It functions as a signaling molecule in nearly all cellular events, while sphingomyelin, generated from ceramide, represents the most abundant sphingolipid subclass in cellular membranes. 
<smiles>CCCCCCCCCCCCC/C=C/[C@@H](O)[C@H](N)CO</smiles><smiles>CCCCCCCCCCCCCCC[C@@H](O)[C@H](N)CO</smiles>

\section{Dihydrosphingosine}<smiles>CCCCCCCCCCCCC/C=C/[C@@H](O)[C@H](N)COP(=O)([O-])O</smiles>

\section{Sphingosine 1-phosphate}<smiles>[R]C(=O)N[C@@H](/C=C/CCCCCCCCCCCCC)[C@@H](O)/C=C/O</smiles>

\section{Ceramide}<smiles>[R]C(=O)N[C@H](/C=C/CCCCCCCCCCCCC)[C@@H](O)/C=C/COP(=O)([O-])OCCN</smiles>

\section{Sphingomyelin}<smiles>[R]C(=O)N[C@H](/C=C/CCCCCCCCCCCCC)[C@@H](O)/C=C/CO[C@H]1O[C@@H](CO)[C@@H](O)[C@H](O)[C@H]1O</smiles>

\section{Glucosylceramide}

Figure 1. Chemical structures of sphingolipids. Sphingosine represents the common sphingolipid backbone as the sphingoid base. Dihydrosphingosine, also known as sphinganine, possesses a saturated sphingoid backbone. Ceramide contains an additional fatty acyl chain via the N-link to the sphingoid base. Sphingosine 1-phosphate, sphingomyelin and glucosylceramide are generated via O-linked modification from sphingosine or ceramide, respectively. Created in ChemDraw ${ }^{\circledR}$. 


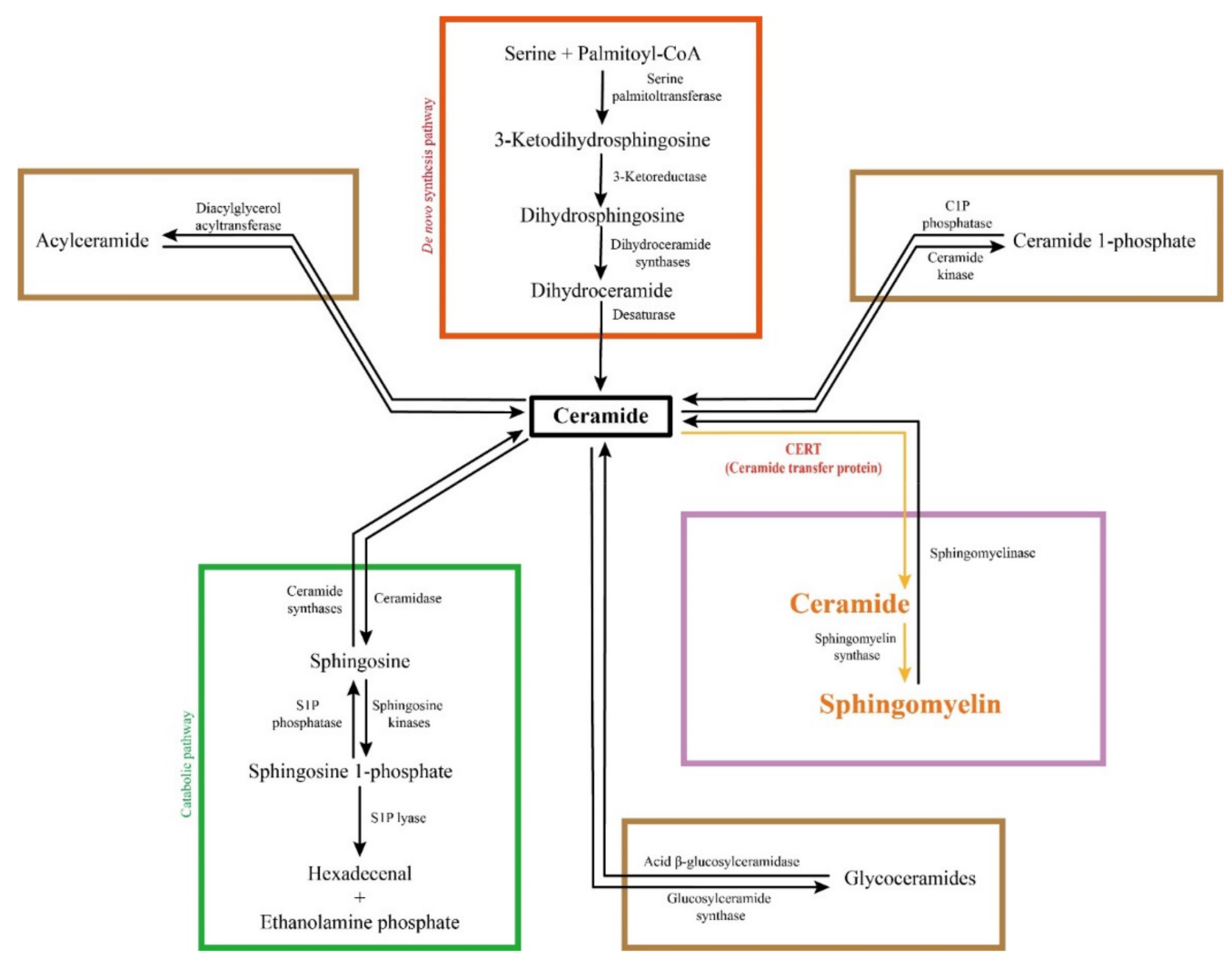

Figure 2. Sphingolipid metabolic network. Ceramide is biosynthesized from amino acid and fatty acid via four steps. It can be degraded in the catabolic pathway into non-lipid products. Meanwhile, ceramide can be converted into complex sphingolipids, such as sphingomyelin, glycoceramides, acylceramide and ceramide 1-phosphate, in a reversible fashion. The majority of ceramide is converted into sphingomyelin, the most abundant sphingolipid species, which is replied on CERT-mediated endoplasmic reticulum to Golgi ceramide transport.

\subsection{Biosynthesis of Sphingolipids}

The first committed step of the de novo biosynthesis of sphingolipids is generating a sphingoid base, as shown in Figure 2. In this step, serine palmitoyl-CoA transferase (SPT) mediates the condensation of two non-sphingolipid molecules, serine and fatty acyl-CoA, to form 3-keto-dh-sphingosine at the cytoplasmic face of the ER [43-45]. SPT is conservatively composed of two large subunits SPT1/Lcb1p and SPT2/Lcb2p in yeast and mammals [46,47]. The third subunit, SPT3 was found later, which can replace SPT2 in a complex with SPT1 [48]. More recently, SPT is found trimeric after the identification of an additional small subunit that is required for maximal enzyme activity [49]. At the cytoplasmic side of the ER, 3-keto-dh-sphingosine is further reduced by 3-keto-dh-sphingosine reductase (KDSR) into dh-sphingosine [43,50]. Subsequently, ceramide is produced via ceramide synthase (CerS, also known as longevity assurance or Lass)-mediated $\mathrm{N}$-acylation of fatty acyl chain onto the sphingoid base [51,52], followed by dh-ceramide desaturasemediated desaturation of dihydro-ceramide in the ER [53,54]. There are six mammalian CerS isoforms, CerS1-CerS6. They exhibit different fatty acyl chain preferences and distinct tissue distribution: CerS1 is mainly expressed in brain, skeletal muscle, and testis and specifically generates C18 ceramides; CerS2 is highly expressed in liver and kidney and selectively produces C22-C24 ceramides; CerS3 is seen in testis and skin and accepts C22-C26 fatty acyls; CerS4, CerS5 and CerS6 are widely expressed in tissues, but CerS4 prefers C18-C20 fatty acyl chains while CerS5 and CerS6 predominantly generate C14-C16 ceramides $[13,55,56]$. Ceramide is central to the sphingolipid metabolic network (Figure 2). It can be degraded into non-lipid products via the catabolic pathway and reversibly converted into complex sphingolipids, such as sphingomyelin and glycoceramides [3]. The 
fatty acyl chain specificity of different CerS determines the generation of not only various ceramides but also diversified complex sphingolipids.

\subsection{Catabolism of Sphingolipids}

In the sphingolipid catabolic pathway, ceramide is deacylated into sphingosine by ceramidases [3]. According to their $\mathrm{pH}$ optimum, five mammalian ceramidase isoforms can be categorized into acid, neutral and alkaline ceramidase. This is also related to their subcellular localization and biological functions at the subcellular level. Acid ceramidase is maturated via proteolysis, and it works to deacylate ceramide in the acidic environment of lysosomes $[57,58]$. Neutral ceramidase in vertebrates is localized to the plasma membrane via the O-glycosylation of its serine/threonine/proline-rich mucin box [59]. Therefore, it is vital for the regulation of sphingosine and S1P signaling across the plasma membrane [60]. Three alkaline ceramidases function in different subcellular compartments [13]. Among them, alkaline ceramidase 1 (ACER1) is an ER-residential enzyme hydrolyzing C24:0 and C24:1 ceramides [61,62], ACER2 is a Golgi-localized enzyme preferably deacylating monounsaturated C18, C20 and C24 ceramides [63,64], while ACER3 is present in both the ER and the Golgi apparatus metabolizing unsaturated long-chain ceramides and dh-ceramides [65]. In ceramidase-mediated hydrolysis, the substrate ceramides are primarily sourced from the degradation of sphingomyelin or glycoceramides via post-Golgi vesicular trafficking [66]. Following this step, sphingosine, the product of ceramidases, is phosphorylated into S1P by sphingosine kinase 1 and 2, which is subsequently lysed by S1P lyase into ethanolamine phosphate and hexadecenal in an irreversible manner [3,67-69]. Sphingosine kinase 1 mainly mediates S1P production at the plasma membrane [70,71], sphingosine kinase 2 dominates the same enzymatic function in the nucleus, mitochondria and ER [72-75], while S1P lyase is an ER-localized enzyme in rodents and humans [76-78]. In addition, sphingosine kinase 1 contributes more to the S1P production in the circulation and cancerous tissues $[18,79,80]$; sphingosine kinase 2 is the predominant isoform in the liver, kidney, heart, pancreatic islets and brain, where it is a critical regulator for cell metabolism, functions and survival [81,82]; whereas S1P lyase is widely expressed in all tissues [83]. Simultaneously knockout of both sphingosine kinases, but not either individual isoform, results in embryonic lethality, indicating the essential roles of S1P and functional redundancy between sphingosine kinase 1 and 2 [84]. Knockout of S1P lyase, the gatekeeper at the exit of the sphingolipid metabolic network, elevates the levels of all sphingolipids and causes death in mice by the age of 8 weeks $[83,85]$.

\subsection{Complex Sphingolipids}

Following de novo biosynthesis in the ER, a large portion of ceramide is converted to complex sphingolipids. This process is featured by a reversible addition of a substitute head group is to the 1-hydroxyl position of ceramide [39]. Therefore, complex sphingolipids are categorized by their diversified head groups into sphingomyelin, ceramide phosphoethanolamine, glycoceramides, ceramide 1-phosphate, acylceramide, etc. [86-90].

The most abundant sphingolipid is sphingomyelin [39,60]. In sphingomyelin synthesis, the phosphorylcholine head is transferred from phosphatidylcholine to ceramide, mediated by sphingomyelin synthases [91-93]. Meanwhile, phosphatidylcholine turns to be diacylglycerol $[87,94,95]$. The conversion between ceramide and sphingomyelin is crucial to lipid cell biology. It determines the cellular content of two major membrane structural lipids, sphingomyelin and phosphatidylcholine, as well as two starring signaling lipids, ceramide and diacylglycerol. There are two sphingomyelin synthases, sphingomyelin synthase 1 and 2. The former one is localized to the trans-Golgi cisterna, while the latter one is present in both trans-Golgi and the plasma membrane $[87,96,97]$. The conversion of newly biosynthesized ceramide at the trans-Golgi contributes the majority of sphingomyelin within the cell, while sphingomyelin production at the plasma membrane represents the recycling of ceramide. Reversibly, sphingomyelin can be hydrolyzed into ceramide, mediated by sphingomyelinases (also known as sphingomyelin phosphodiesterases or SMPDs) 
at different subcellular organelles [98,99]. Similar to ceramidases, sphingomyelinases are classified into acid, neutral and alkaline types, according to their $\mathrm{pH}$ optimum [98,99]. Acid sphingomyelinase (SMPD1) is maturated via C-terminal proteolytic processing in lysosomes, where it hydrolyzes endolysosomal sphingomyelin [100]. Further N-terminal proteolysis in endolysosomes allows acid sphingomyelinase to be secreted extracellular milieu [101,102]. The secreted form of the enzyme can metabolize sphingomyelin at the plasma membrane and in plasma under a neutral $\mathrm{pH}$ environment [103,104]. There are four neutral sphingomyelinases, including neutral sphingomyelinase 1-3 and mitochondriaassociated neutral sphingomyelinase. Among them, neutral sphingomyelinase 1 (SMPD2) is localized to the ER [105], the Golgi apparatus [105] and the nucleus [106]; neutral sphingomyelinase 2 (SMPD3) travels between the plasma membrane and the Golgi apparatus $[107,108]$; neutral sphingomyelinase 3 (SMPD4) resides in the ER as well as the Golgi apparatus [109]; while the subcellular localization of mitochondria-associated neutral sphingomyelinase is told from its name [110]. Alkaline sphingomyelinase is also known as nucleotide pyrophosphatase/phosphodiesterase 7, which is mainly expressed in the intestine [111]. Within the cell, this enzyme resides in endosome-like structures near the plasma membrane [111,112].

In addition to being converted into sphingomyelin, ceramide can be catalyzed by a sphingomyelin synthase 1 homologous protein, named sphingomyelin synthase related protein, to ceramide phosphoethanolamine at the luminal side of the ER [88]. However, the content of ceramide phosphoethanolamine is 300-fold less than sphingomyelin synthase 1-produced sphingomyelin [88]. Another ceramide-derived phosphosphingolipid is ceramide 1-phosphate that possesses the simplest head group as phosphate. Ceramide 1-phosphate is produced by ceramide kinase mainly at the cytosolic face of the trans-Golgi, which is required for eicosanoid production [113-115]. Ceramide 1-phosphate can be dephosphorylated by ceramide phosphatase at the plasma membrane [116]. Following sphingomyelin, the second abundant complex sphingolipid is glycosphingolipid, such as galactosylceramide and glucosylceramide. Galactosylceramide is produced with uridine diphosphate-galactose by ceramide galactosyltransferase at the luminal side of the ER [117]; while glucosylceramide is synthesized with uridine diphosphate-glucose by glucosylceramide synthase at the cis-Golgi [118]. Once transported from the ER to the Golgi apparatus, galactosylceramide serves as a precursor for generating more complex glycosphingolipids, such as sulfatides and ganglioside GM4 [119,120]. In contrast, glucosylceramide synthesis is the first rate-limiting step in the production of more than 3000 glycosphingolipids, including lactosylceramides, gangliosides GM1, GM2 and GM3 [39,121]. In the revered process, galactosylceramide and glucosylceramide can be hydrolyzed into ceramide by galactosylceramidase and glucocerebrosidase in lysosomes, respectively [122,123]. Recently, ceramide is found to be acylated into a neutral lipid by diacylglycerol O-acyltransferase 2 at lipid droplets $[90,124]$.

\section{CERT-Mediated Intracellular Sphingolipid Trafficking}

\subsection{Two Modes of Intracellular Sphingolipid Trafficking}

As introduced in the previous section, enzymes that mediate sphingolipid metabolism have distinct subcellular localization and thus access different subcellular sphingolipid pools. Interestingly, ceramide is biosynthesized in the ER, but enzymes that convert ceramide to sphingomyelin or glycoceramides are localized to the Golgi apparatus. Similarly, sphingomyelin is generated by sphingomyelin synthases in the Golgi apparatus, but hydrolysis of sphingomyelin into ceramide by sphingomyelinases mainly takes place in lysosomes or the plasma membrane. This led researchers to interrogate how sphingolipids travel from their biosynthesis sites to other subcellular venues for functioning. In general, this is not completely understood. There are two modes of intracellular sphingolipid trafficking - vesicular transport and lipid transfer protein (LTP)-mediated transport (or non-vesicular transport); both contribute to the diversified distribution of sphingolipids among subcellular compartments. Sphingomyelin is delivered from the Golgi to the plasma 
membrane via vesicular transport, followed by further distribution to lysosomes via endocytosis [125]. Ceramide can also travel from the ER to the cis-Golgi in lipoprotein or protein transport vesicles [126]. In comparison, LTP-mediated intracellular sphingolipid transport is more efficient and specific. So far, a few sphingolipid-associated LTPs have been identified, including CERT (ceramide transport from the ER to the trans-Golgi [34], Ceramide-1-phosphate transfer protein (ceramide 1-phosphate transport from the transGolgi network to the plasma membrane and other intracellular membranes) [127], four phosphate adapter protein 2 (glucosylceramide transport from the cis-Golgi to the transGolgi [128] and glycolipid transfer protein (glucosylceramide redistribution) [129]. Among these, CERT is the first and best-characterized LTP. It specifically transports ceramide from the ER to the trans-Golgi allowing the subsequent sphingomyelin synthesis, with no impacts on ceramide transfer to the cis-Golgi for glycosphingolipid production other sphingolipid trafficking $[34,130]$.

\subsection{Schematic Structure of CERT}

CERT is encoded by the CERT1 gene, with two protein variants in 624 and 598 amino acids, referred as to $C_{E R T_{L}}$ and CERT, respectively (Figure 3). Its alternate names include GPBP (normally refers to CERT $_{\mathrm{L}}$ ), Col4a3bp and STARD11 (both refer to the short-form). The amino acid sequence in the short-form CERT is identical to the long-form, except for the lack of the second serine-rich motif (SRM) in the middle region (MR) [131]. CERT $\mathrm{L}_{\mathrm{L}}$ was initially identified by Raya et al. in 1999, which is a non-conventional serine/threonine kinase often found in the extracellular matrix or associated with the plasma membrane [132,133]; in contrast, the short-form of CERT functions as a ceramide transporter shuttling between the ER and the trans-Golgi, which was first addressed by Hanada et al. in 2003 [34]. The CERT protein comprises an N-terminal Pleckstrin Homology $(\mathrm{PH})$ domain composed of approximately 120 amino acids, a C-terminal steroidogenic acute regulatory protein (StAR)related lipid transfer (START) domain with about 230 amino acids and an MR between them [134]. In the MR, short-form CERT possesses an SRM at amino acid 127-152 and a two phenylalanines in an acidic tract (FFAT) motif at amino acid 321-327 [134].

$\mathrm{CERT}_{\mathrm{L}}$

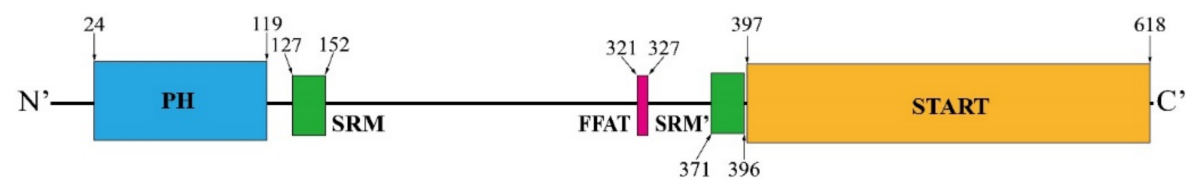

CERT

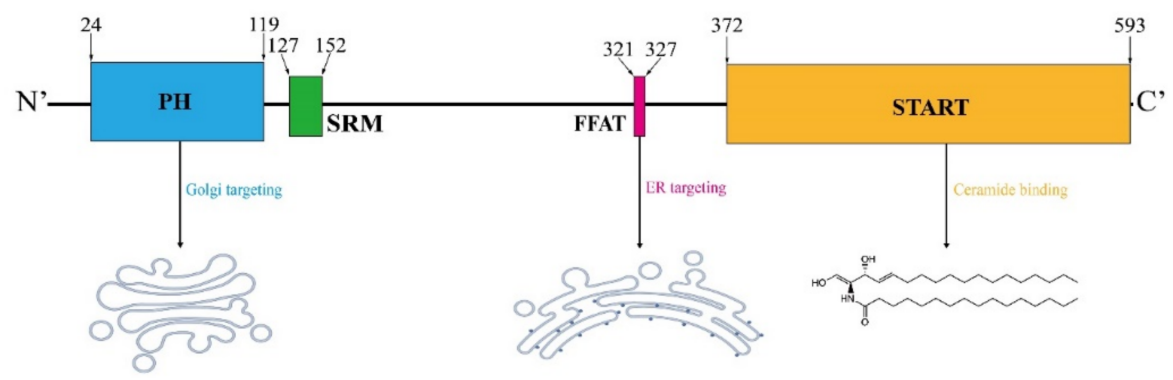

Figure 3. Schematic structure of CERT. The structural elements are colored as follows: Pleckstrin homology (PH) domain (blue), serine-rich motif (SRM, green), two phenylalanines in an acidic tract (FFAT) motif (pink), StAR-related lipid-transfer (START) domain (orange), major phosphorylation sites (red). The short-form CERT lacks a SRM in the proximity of START domain, as compared with the long-form variant. Amino acid sequence is adapted from [134].

\subsection{START Domain in CERT}

In humans, there are 15 proteins with the START domain (named STARD1-15) [135]. CERT is the STARD11, and its START domain specifically recognizes ceramide $[136,137]$. In 2008, Kudo et al. resolved the crystal structure of the START domain at the C-terminus of CERT in two conformations: an apo-form at 2.2- $\AA$ resolution and ceramide-bound 
form at 1.4- $\AA$, which revealed how this domain interacted with ceramide [136]. A large amphiphilic cavity located at the center of the START domain is responsible for the binding of one ceramide molecule [136]. The cavity is formed by $\beta$-strands covering three $\alpha$ helices and the $\Omega$-loops $[66,136,137]$. Specifically, the amphiphilicity is contributed by 26 hydrophobic and 10 polar/charged amino acid residues within the cavity [136]. The amphiphilic nature of the cavity in the START domain permits ceramide extraction, trap and discharge [136]. This physical compatibility between the lipid and the START domain is consistent with how ceramide can flip flop in between the subcellular membranes [137]. The physical and chemical properties of the START domain result in the selective receipt and transport of ceramide molecules with particular length of saturated fatty acyl chain ranging from $\mathrm{C} 14$ to $\mathrm{C} 20$ and, less efficiently, with C22 and C24 mono-unsaturated fatty acyl chain [138]. However, it has insufficient space for C24:0 [138]. Thus, the transfer of C24:0 ceramide is rarely observed $[94,136,137]$, which might determine the composition of sphingomyelin species $[66,139]$. Compared with other proteins in the START family, CERT stands out as it possesses a PH domain and an FFAT. Although the START domain is solely responsible for the ceramide binding activity in CERT, it is not sufficient for the ER-to-Golgi ceramide transport in vivo [140]. CERT mutants lacking the PH domain and FFAT motif cannot transport ceramide efficiently, as evidenced by a reduced level of sphingomyelin production $[34,66,138,141]$.

\subsection{PH Domain in CERT}

PH domain specifically binds to phosphatidylinositol phosphates (PIPs). For example, the $\mathrm{PH}$ domain in phospholipase $1 \delta$ binds to $\mathrm{PI}(4,5) \mathrm{P}_{2}$ [142], $\mathrm{PI}(3,4,5) \mathrm{P}_{3}$ recruits protein kinase B/Akt to the plasma membrane [143-145], OSBP exchanges lipids between the ER and the Golgi apparatus by binding to PI(4)P [144] and class III PI 3-kinase Vps34 docks via PI(3)P for its endosomal targeting [145]. The PH domain of CERT preferably binds to $\mathrm{PI}(4) \mathrm{P}$ that resides in the trans-Golgi and the trans-Golgi network (TGN) $[34,146]$. Surface plasmon resonance analysis has confirmed that the PH domain of CERT exhibits a higher affinity to PI(4)P-bound liposomes than PI(4,5)P2-embedded liposomes [140]. However, the PI(4)P affinity of PH-CERT is much weaker than PH-OSBP [147]. In line with this, overexpression of OSBP can inhibit ceramide transfer to the Golgi by competing in binding to the PI(4)P [148]. This work indicates that the PH domain is essential for the CERT function. Indeed, G67E mutation in the PH domain abrogates PI(4)P binding as well as ceramide transport function of CERT $[34,66]$. Sugiki et al. revealed the three-dimensional structure of the PH domain in CERT using nuclear magnetic resonance [140]. Structurally, a basic groove was identified near the PI(4)P recognition site, which helps to orientate the PH domain for a more efficient search for PI(4)P in the Golgi $[140,149]$. Interestingly, the crystal structure of the PH-START complex shows that START can bind to the PH at the PI(4) binding site [150]. Disruption of the binding between START and PH reinforces the Golgi targeting of CERT [150]. These demonstrate an intramolecular regulation mechanism, fine-tuning the subcellular localization of CERT.

\subsection{FFAT Motif in CERT}

FFAT is a short peptide motif with the canonical consensus sequence of EFFDAxE, which is present in the MR between the PH and the START domains in CERT [151]. This motif is essential for the ER targeting of CERT via the physical interaction with vesicleassociated membrane protein-associated proteins (VAPs) [66,141,152]. There are two VAPs in mammals, VAP-A and VAP-B, that provide anchors for LTPs at the cytoplasmic face of the ER [152]. Other than CERT, many LTPs, such as oxysterol binding protein (OSBP) and its related proteins (ORP1, ORP2, ORP4), Nir2 and STARD3, also transport their lipid cargos in an FFAT motif-dependent manner [153]. D324A mutation in the FFAT motif of CERT results in the loss of ceramide binding and transport [141]. 


\subsection{CERT-Mediated Ceramide Transport}

CERT transports ceramide from the ER to the trans-Golgi at their membrane contact site $[66,134]$. It can dramatically accelerate C16 ceramide transfer from days to $10 \mathrm{~min}$ in a cell-free system [34]. CERT-mediated ceramide transfer determines the cellular content of both ceramide and sphingomyelin. Knockdown of CERT causes ceramide accumulation in zebrafish embryos [154] and human colon cancer cells [155], whereas overexpression of CERT reduces ceramide level in C2C12 myoblasts [156]. In contrast, CERT is critical for sphingomyelin synthesis, as it recovers sphingomyelin levels in cells deficient in this sphingolipid [34]. CERT-deficient cells show a dramatic decrease in sphingomyelin levels but still maintain the level of glucosylceramide $[34,156,157]$. Ablation of CERT profoundly decreases sphingomyelin level in Drosophila melanogaster [158] and MCF-7 breast cancer cells [159]. The embryonic cells in CERT knockout mice exhibit a reduced level of sphingomyelin in the plasma membrane and an increased level of ceramide in the ER and mitochondria $[160,161]$. Consistently, adeno-associated virus-mediated overexpression of $\mathrm{CERT}_{\mathrm{L}}$ decreases ceramide but increases sphingomyelin in the cortex of mice [162].

\subsection{Regulation of CERT Function}

CERT protein can be regulated by phosphorylation at least in two regions. Sequential phosphorylation occurs in the SRM [163-165] and serine 315 within the FFAT motif [166]. Using MALDI-TOF mass spectrometry, a characteristic "S/T-X-X" repeat was identified in the SRM of CERT protein [163]. S132, the most N-terminal serine, is known as the leading phosphorylation site required for the phosphorylation of the following serine and threonine residues [163]. S132 phosphorylation by protein kinase D decreases the PI(4)P binding and ceramide transfer $[164,167]$. The S132A mutation leads to the hypophosphorylation of CERT, which exhibits more powerful ceramide transfer activity as compared with the wild-type protein [163]. In line with this, the S132L mutation also results in the hypophosphorylation of CERT, which is associated with an enhanced sphingomyelin production [168]. The serial phosphorylation in the SRM by casein kinase $1 \gamma 2$ also inactivates CERT and results in a reduction in sphingomyelin level [165]. The hyperphosphorylation in SRM also hinders PH domain access to PI(4)P, and thus it dissociates CERT from the Golgi, leading to the inactivation of CERT [169]. In contrast, myriocin (specific serine palmitoyltransferase inhibitor) and methyl- $\beta$-cyclodextrin (cholesterol-depleting reagent) can dephosphorylate and activate CERT [163]. The SRM can also be dephosphorylated by protein phosphatase $2 \mathrm{C} \varepsilon$ [170]. Knockdown of protein phosphatase $2 \mathrm{C} \varepsilon$ attenuates the association between CERT and VAPA and reduces sphingomyelin levels [170]. Recently, G243R mutation outside of SRM, FFAT, START or PH, regulates the conformational change of CERT, resulting in easy access of phosphatases to the SRM [168]. Opposing to phosphor-inhibition in the SRM, phosphorylation at S315 in the FFAT motif facilitates the VAP binding (ER targeting) of the protein, leading to an enhanced ceramide transport to the Golgi [166]. Consistently, myriocin promotes the S315 phosphorylation and activate CERT [171]. However, the kinase that is responsible for S315 phosphorylation has not been identified yet.

There is a negative feedback loop in CERT-dependent sphingomyelin production. During the synthesis of sphingomyelin in the trans-Golgi, diacylglycerol is co-produced [172]. Diacylglycerol recruits and activates protein kinase $\mathrm{D}$, which inhibits CERT function via S132 phosphorylation [164]. In addition, PI(4)P availability is crucial for the CERT function. Genetic knockdown or pharmacological inhibition of PI 4-kinase III reduces PI(4)P level at the trans-Golgi, and thus it inhibits ceramide transfer [148]. OSBP depletes PI(4)P at the trans-Golgi in exchange for cholesterol [144]. Overexpression of OSBP inhibits CERTmediated ceramide transfer [148], whereas blocking OSBP-mediated PI(4)P/cholesterol exchange by 25-hydroxylcholesterol promotes CERT function [173]. In OSBP-mediated regulation of CERT function and sphingomyelin synthesis, PI 4-kinase II $\alpha$, but not PI 4-kinase $\mathrm{III}$, is required for $\mathrm{PI}(4) \mathrm{P}$ homeostasis [174]. Interestingly, sphingomyelin production triggers dephosphorylation of PI(4)P, inhibiting CERT function and limiting over-production 
of sphingomyelin [175]. In a lipid transfer assay, no ceramide can be extracted by CERT from vesicles made of 100\% palmitoyl-sphingomyelin [176]. Furthermore, CERT can be cleaved by caspases at its D213 residue during apoptosis [177].

\section{Biological Function of CERT and $\mathrm{CERT}_{\mathrm{L}}$}

CERT exerts its biological functions by the regulation of sphingomyelin and ceramide levels at different subcellular compartments. Sphingomyelin is a chemically inert lipid and acts as a major component in the outer leaflet of the plasma membrane [178]. In particular, it interacts with cholesterol to form discrete lipid-rich microdomains in the plasma membrane, providing platforms for signaling proteins anchoring and functioning $[179,180]$. Sphingomyelin at the plasma membrane can also facilitate endocytosis [181]. At the trans-Golgi, sphingomyelin is believed to determine the protein sorting [164]. As evidenced in a few studies on manipulating sphingomyelin synthases that alter sphingomyelin content, sphingomyelin is suggested to promote cell survival [182,183], proliferation $[97,184-186]$ and migration $[29,187]$. In contrast, ceramide is well established as a pro-apoptotic signal [188-190] and an inducer of cell cycle arrest [190]. Thus, the CERT might be a determinant of cancer development by dictating the ratio of ceramide to sphingomyelin. In addition to regulating ceramide and sphingomyelin, $\mathrm{CERT}_{\mathrm{L}}$ is also implicated in several cellular and physiological functions via physical interaction with other proteins $[162,191,192]$. Here we summarize the biological functions of both short and long-form of CERT (Figure 4).

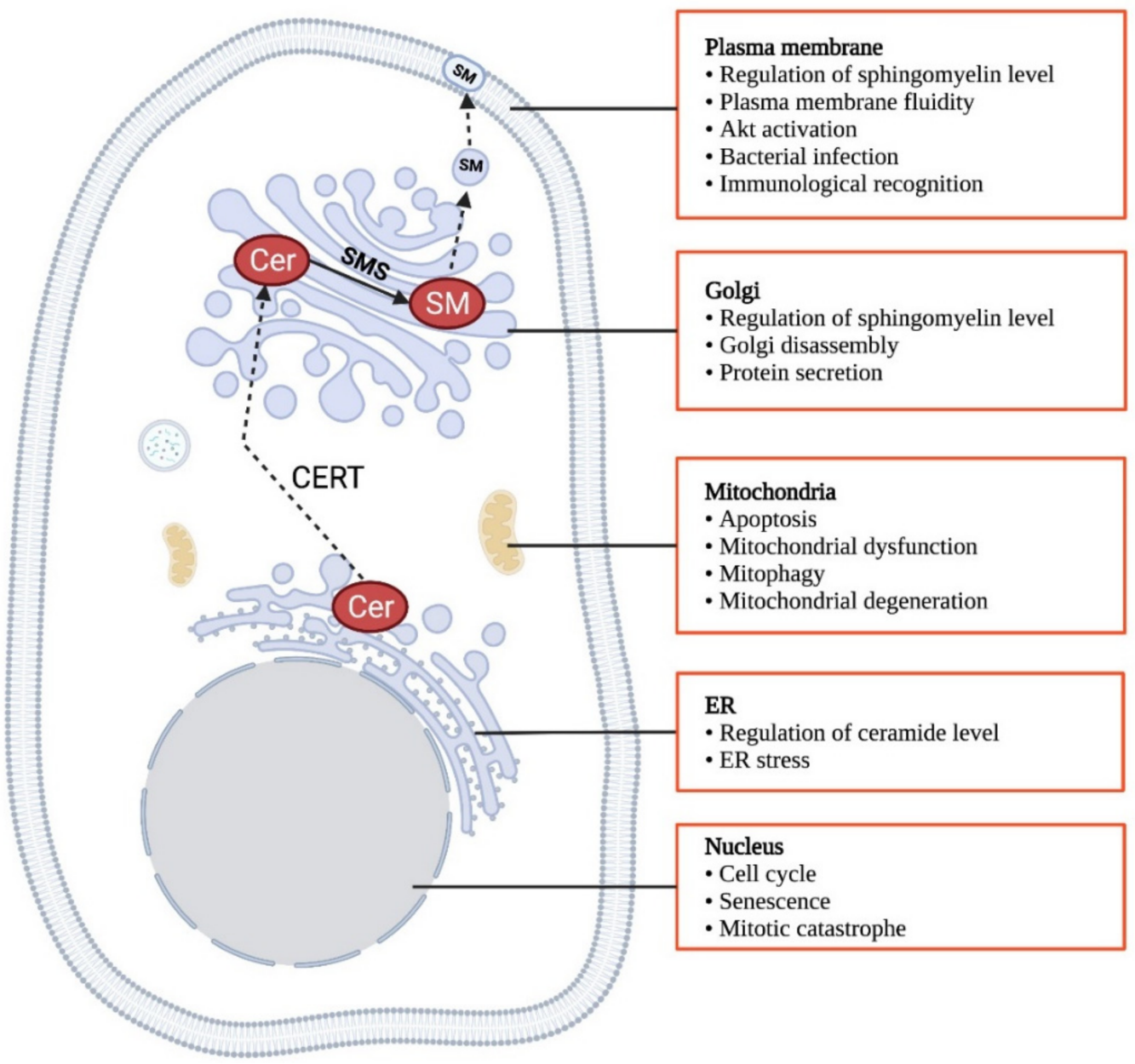

Figure 4. Biological functions of CERT. Created in Biorender.com (accessed on 11 November 2021). 


\subsection{Biological Functions of Short-Form CERT}

4.1.1. Embryonic Survival and Life Span

CERT is essential for embryonic survival. Knockout of CERT results in embryonic death around E11.5 from a failed cardiovascular system in mice [160]. It reduces the levels of total cellular sphingomyelin and plasma membrane-bound sphingomyelin by more than $60 \%$, while it increases the ceramide level in the ER and mitochondria with no change in total cellular ceramide content [160]. In accord, CERT knockout embryonic cells exhibit abnormal mitochondria morphology lacking cristae, ER stress, cell cycle arrests with a delayed entry into $\mathrm{G} 2 / \mathrm{M}$ phase and inactivation of cell survival signal protein kinase B/Akt, attributed to increased ceramide level in the ER and mitochondria [160]. Knockdown of CERT also causes embryonic lethality in zebrafish because of increased ceramide levels and apoptosis in the brain and somites [154]. Knockout of CERT in Drosophila melanogaster leads to early death between day 10 to 30, whereas control flies live 75 to 90 days [158]. This is mainly due to a dramatically decreased sphingomyelin level at the plasma membrane; as a result, it increases the plasma membrane fluidity and the susceptibility to oxidative stress [158].

\subsubsection{Apoptosis}

To understand the roles of ceramide in mitochondria-dependent apoptosis, Jain et al. developed a CERT mutant, mitoCERT, that is exclusively localized to mitochondria by replacing the $\mathrm{PH}$ domain with outer mitochondrial membrane anchor sequence of A-kinase anchor protein 1 [193]. mitoCERT can deliver ceramide from the ER to mitochondria instead of the trans-Golgi [193]. Overexpressing mitoCERT promotes cytochrome c release, activation of caspase- 9 and cleavage of PARP, all classic effectors in the intrinsic apoptosis pathway, in HeLa, ovarium carcinoma OVCAR3 and SKOV1, non-small lung carcinoma A549 and colon carcinoma HCT116 cells [193]. This effect is dependent on the ceramide transfer from the ER to mitochondria [193]. The same laboratory further developed a rapamycin-inducible version of mitoCERT, by which they demonstrate that mitochondrial ceramide triggers Bax translocation to mitochondria during apoptosis [194]. These tools well address the pro-apoptotic role of ceramide, but they are not used for interpreting the role of wild-type CERT in apoptosis. Conversely, wild-type CERT is considered anti-apoptotic. Depletion or inhibition of CERT causes accumulation of ceramide in the ER $[154,155,160]$. Knockdown of CERT predisposes HCT-116 human colon cancer cells, MDA-MB-231 human triple-negative breast cancer cells and A549 human lung carcinoma cells to chemotherapeutic agents-induced ER stress and apoptosis [195]. Meanwhile, CERT ablation sensitizes HER2+ breast cancer cell lines BT474, HCC1954 and SK-BR3 to paclitaxel, doxorubicin and cisplatin-induced cell death [155]. $\gamma$-tocotrienol, a member of the vitamin E family, downregulates CERT and induces apoptosis in MIA PaCa-2 pancreatic cancer cells [196]. Gedunin, a limonoid product, inhibits CERT-mediated ceramide extraction from the ER, reduces cellular sphingomyelin level by approximately $50 \%$ and exhibits anticancer activity in vitro $[197,198]$. Inhibition of CERT by HPA-12 sensitizes keratinocytes to ultraviolet B-induced apoptosis [199]. In TNF $\alpha$ and anisomycin-induced apoptosis, CERT dissociates from the Golgi due to the Golgi disassembly, followed by cleavage by active caspase-2, 3 and 9 [177]. This also occurs in palmitate-induced apoptosis [156].

\subsubsection{Senescence and Mitosis}

In murine embryonic cells, CERT deficiency causes accumulation of glucosylceramide instead of ceramide in the ER and mitochondria [161]. This leads to the ER stress, mitochondrial dysfunction, overproduction of reactive oxygen species, increased mitophagy, eventually resulting in G1 phase arrest and premature senescence phenotype in cells [161]. Furthermore, downregulation of CERT is associated with mitochondrial dysfunction and oocyte ageing [200]. Knockdown of CERT by siRNA, inhibition of CERT by HPA-12 or treatment with C6-ceramide induces a mitotic arrest in HCT-116 cells in the presence of pa- 
clitaxel [195]. Knockdown of CERT results in mitotic catastrophe in a lysosomal membraneassociated protein 2-dependent manner in paclitaxel-treated HCT-116 cells [155].

\subsubsection{Akt Signaling}

There are some conflicting reports on the regulation of Akt signaling by CERT. Knockdown of CERT reduces sphingomyelin level by $44 \%$ in MCF-7 cells [159]. However, in contrast to the presumably pro-survival role of sphingomyelin, knockdown of CERT and reduction in sphingomyelin improves epidermal growth factor-triggered Akt and ERK activation, which promotes cancer cell migration and focal clustering [159]. In support of this, sphingomyelin synthase 2 deficiency decreases sphingomyelin levels at the plasma membrane, which improves insulin resistance in diet-induced obese mice [201]. Against the above evidence, inhibition of CERT by HPA-12 suppresses Akt translocation and activation at the plasma membrane, sensitizing paclitaxel-induced apoptosis in HCT-116 human colon cancer cells [195]. In addition, downregulation of CERT protein level is associated with insulin resistance in palmitate-treated $\mathrm{C} 2 \mathrm{C} 12$ murine skeletal muscle cells and the gastrocnemius muscle isolated from mice on a high-fat diet for 12 weeks [156]. Knockdown of CERT impairs insulin signaling in the presence of palmitate-induced lipotoxicity, whereas overexpression of CERT reduces ceramide level by 4.1 -fold and restores insulin sensitivity in palmitate-treated C2C12 myoblasts [156].

\subsubsection{Golgi Disassembly and Protein Secretion Sorting}

The morphological elongation of the Golgi apparatus is induced at $1 \mathrm{~h}$ after treatment with TNF $\alpha$ or anisomycin in HeLa cells, which is followed by structural disruption at $4 \mathrm{~h}$ [177]. This change can be abrogated by the pan-caspase inhibitor, indicating it results from apoptosis [177]. The caspase-2, 3 and 9-mediated cleavage of CERT at its D213 inactivates CERT, leading to the Golgi disassembly [177]. In addition, CERT is implicated in the regulation of protein secretion from the Golgi apparatus [164]. Overexpression of CERT elevates protein kinase D activity and augments protein kinase D-dependent protein secretion [164].

\subsubsection{Oxidative Stress}

Ceramides have long been established to induce reactive oxygen species (ROS) production in mitochondria, leading to oxidative stress [202-205]. Specifically, C16 ceramide is a major inducer of ROS and oxidative stress, as demonstrated by the differential regulation of ceramide species in CerS2-deleted mouse livers [206]. Sphingomyelin is negatively correlated with membrane fluidity [207]; while increased plasma membrane fluidity is associated with enhanced oxidative stress [208]. Therefore, sphingomyelin may have antioxidant effects, and restricting the conversion of ceramide to sphingomyelin may potentiate oxidative responses. Indeed, knockdown of sphingomyelin synthase 1 sensitizes neuroblastoma Neuro 2A cells to $\mathrm{H}_{2} \mathrm{O}_{2}$-induced oxidative stress and cell death [209], while functionally null nutant of CERT results in oxidative stress in flies [158]. Glutathione peroxidase 8 is a scavenger of ER-derived $\mathrm{H}_{2} \mathrm{O}_{2}$ [210]. Knockdown of this enzyme increases CERT expression, along with a decreased ceramide level and an increased sphingomyelin level in HeLa cells [211]. Meanwhile, the polyunsaturated fatty acid (PUFA) content in phospholipids is decreased, as an adaptive mechanism leading to phospholipid-enriched membranes less prone to oxidative stress [211] and more resistant to free radicals and chemotherapies in cancer cells [212]. This suggests a potential link between CERT and PUFA, which warrants further investigation.

\subsection{Biological Functions of Long-Form CERT}

\subsubsection{Neurotoxicity and Neurogenesis}

$\mathrm{CERT}_{\mathrm{L}}$ is highly expressed in neurons of the cerebral cortex, formation of the hippocampus, basal ganglia and the olfactory and nuclei of the thalamus than other regions of the adult rat brain, suggesting it might play a critical role in neuron functions of the central 
nervous system [213]. CERT $\mathrm{L}_{\mathrm{L}}$ can physically interact with amyloid precursor protein [162]. $\mathrm{CERT}_{\mathrm{L}}$ inhibits the spontaneous fibrillization of amyloid $\beta$ in vitro and protects SHSY-5Y human neuroblastoma cells from amyloid $\beta$-induced toxicity [162]. CERT $\mathrm{L}_{\mathrm{L}}$ level is reduced in the cortex of mice with Alzheimer's disease, while ceramide level is elevated in accord $[162,214]$. Adeno-associated virus-mediated overexpression of $\mathrm{CERT}_{\mathrm{L}}$ for 12 weeks significantly decreases C16:0 ceramide but increases levels of C16:0, C18:0, C18:1, C20:0, $\mathrm{C} 22: 0$ and $\mathrm{C} 24: 1$ sphingomyelin in the cortex, and it ameliorates amyloid $\beta$ pathology in 5XFAD mice [162]. Administration of mice with CERT inhibitor HPA-12 reverses all of these phenotypes [162]. In addition, CERT can optimize direct membrane trafficking and/or apical membrane signaling in neural stem cells during neurogenesis [215].

\subsubsection{Bacterial and Viral Infection}

In Chlamydia-infected cells, CERT is recruited to the inclusion membrane, forming the ER-Chlamydial inclusion membrane contact site [216]. This facilitates ceramide transport from the ER to the inclusion membrane $[217,218]$ and the subsequent sphingomyelin synthesis $[217,218]$. Sphingomyelin is then uptaken by the Chlamydial membrane, which is required for its growth and replication [219]. Knockout of CERT via CRISPR/Cas9 approach decreases Chlamydial infection [220]. In addition, Chlamydia proliferates and forms infective progeny dependent on CERT, but not sphingomyelin synthases [217]. CERT is also implicated in Hepatitis $C$ maturation and secretion [221]. Protein kinase D suppresses Hepatitis $C$ virus secretion by phosphor-inactivating CERT, which can be reversed by overexpression of non-phosphorylatable CERT mutant S132A [221].

\subsubsection{Immunological Recognition}

Apoptotic cells are cleared by phagocytes, which requires their binding to the complement component $\mathrm{C1}$ [ [222] via serum amyloid $\mathrm{P}$ component [191]. $\mathrm{CERT}_{\mathrm{L}}$ physically interacts with the serum amyloid P component, and this interaction is inhibited by C1q [191]. Both CERT ${ }_{\mathrm{L}}$ and CERT directly bind to $\mathrm{C1q}$, leading to complement activation [192]. The co-localization of $\mathrm{CERT}_{\mathrm{L}}$ and $\mathrm{C} 1 \mathrm{q}$ was also found in apoptotic cells, which might be involved in the recognition of apoptotic cells by C1q [192]. Transgenic overexpression of CERTL in non-lupus-prone mice induces deposition of IgA in the glomerular basement membrane, leading to immune complex-mediated glomerulonephritis [223].

\section{Role of CERT in Human Cancers}

At the cellular level, CERT deficiency is shown to cause the imbalance between ceramide and sphingomyelin, resulting in ER stress, mitochondrial-dependent apoptosis, cell cycle arrest and inactivation of the pro-survival master regulator Akt. These suggest CERT might be a cancer-promoting factor. However, the role of CERT has never been studied in any animal work via genetic manipulation or pharmacological inhibition, and thus the direct evidence is missing. Here we summarize all clinical evidence regarding CERT expression levels in different human cancers (Figure 5), aiming to raise readers' attention in their future research. 


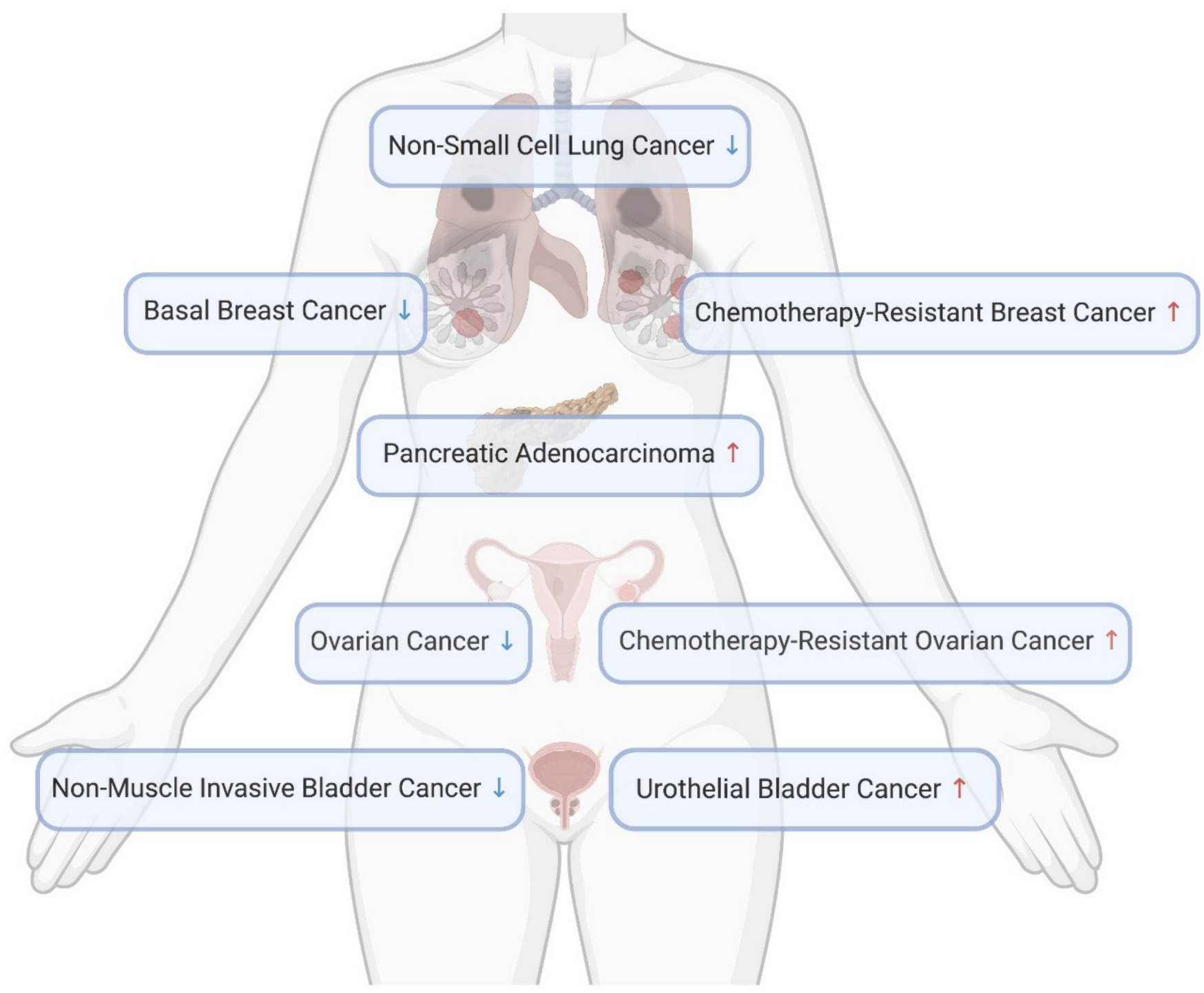

Figure 5. CERT level changes in cancers. Created in Biorender.com (accessed on 11 November 2021).

\subsection{High CERT Expression Associated with Cancer}

In support of the hypothesis that CERT promotes cancer, its mRNA level is upregulated by three-fold in ovarian cancer patients after receiving three cycles of neoadjuvant paclitaxel, which is associated with drug resistance [195]. Through an RNA interference functional screening, CERT was identified as one of the 14 genes that confer resistance to paclitaxel in triple-negative breast cancer cells [224]. CERT was also found as a major contributor and an independent predictor of paclitaxel resistance in the MDA cohort and MDA/MAQC II clinical cohorts (GSE16716) of breast cancer [224,225]. High CERT expression is associated with poorer breast cancer outcomes, whereas low CERT expression is correlated to better chemotherapeutic outcomes in a cohort of Leeds Teaching Hospitals, UK [155]. A similar relationship between CERT expression and relapse-free survival was observed through the mining in an online breast cancer database [226]. We searched the information of CERT in Gene Expression Profiling Interactive Analysis 2 (GEPIA 2) via http:/ /gepia2.cancer-pku.cn (accessed on 10 November 2021) [227,228]. As shown in Figure 6, in all 31 types of cancers, the CERT level is significantly higher in pancreatic adenocarcinoma, as compared with the normal tissue. 

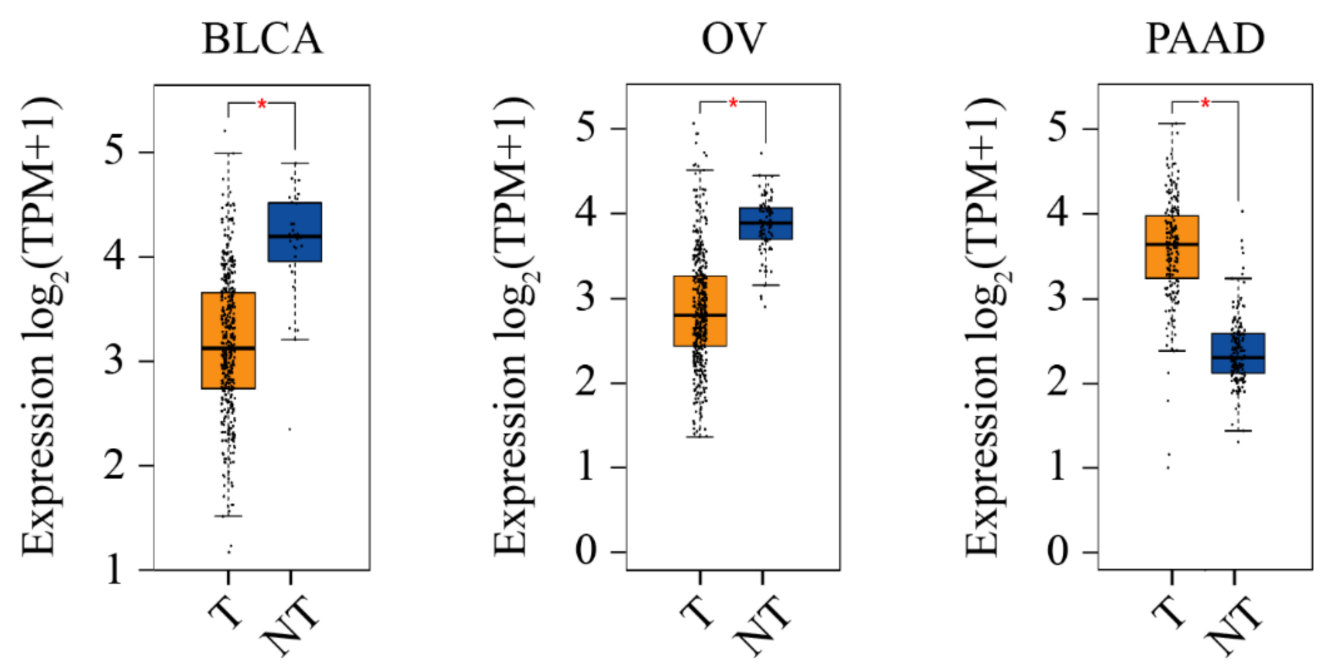

Figure 6. CERT expression level in three cancers. On the GEPIA 2 platform, the CERT expression level is analyzed using expression DIY with ANOVA $(\log 2 \mathrm{FC}=1$, q-value cutoff $=0.01)$ and the matching of TCGA and GTEx data. The * symbol indicates the statistical significance. BLCA, urothelial bladder carcinoma; $\mathrm{OV}$, ovarian cancer; PAAD, pancreatic adenocarcinoma; TPM, transcripts per million. The graph is adapted from GEPIA 2 and edited in Adobe Illustrator.

\subsection{Low CERT Expression Associated with Cancer}

Opposing to the hypothesis that CERT promotes cancer, its mRNA expression is significantly lower in human basal breast cancers compared with non-basal tumors (GSE1561/ GSD1329 and GSE2744/GSD2250, $p<0.002$;) and normal breast tissues (GSE2744/GSD2250, $p=0.013)[159,229,230]$. CERT protein is also lowly expressed in basal breast cancer cell lines, such as MDA-MB-157, 231, 468 and HS-578T, in comparison with that in luminal breast cancer lines, such as MCF-7, BT474, MDA-MB-453, SK-BR3 and ZR751 [159]. In addition, CERT is lowly expressed in progressing non-muscle invasive bladder cancer as compared with non-progressing tumors obtained from hospitals in Denmark, Sweden, Spain and England [231]. Further, high CERT mRNA expression is correlated with better survival in non-small lung cancer patients in China [232]. In addition, searching in GEPIA2 (accessed on 10 November 2021), we have found that CERT level is significantly lower in ovarian cancer and urothelial bladder carcinoma, as compared with the normal tissues (Figure 6).

\subsection{Differential CERT Expression in Different Cancer Contexts}

According to the available information, CERT is often found highly expressed in human cancers undergoing chemotherapies $[155,195,224]$, which indicates a role of CERT in drug resistance. CERT mRNA level is significantly increased over 3-fold in ovarian cancer patients after three cycles of neoadjuvant paclitaxel [195]. CERT mRNA expression is also elevated in human colon cancer HCT-116 cells after $8 \mathrm{~h}$ treatment with paclitaxel [155]. Mechanistically, a high expression level of CERT reduces ceramide, and thus it alleviates drug-induced ER stress and activates pro-survival PI3K/Akt signaling in ovarian cancer and breast cancer cells $[195,224]$. The same research group has also identified that deletion of CERT causes an accumulation of ceramide that is required for the initiation of autophagic death in breast cancers treated with chemotherapeutic agents [155]. To better understand the role of CERT in drug resistance, CERT expression should be examined in cancer cohorts with chemotherapies other than paclitaxel, and the comparison should be made between subjects who had successful and failed chemotherapies.

In contrast, low CERT expression is usually reported in cancer cohorts, with no drug treatment information $[159,231,232]$. In the absence of chemotherapies, knockdown of CERT promotes PI3K/Akt activation in response to epidermal growth factor (EGF), which is associated with sphingomyelin loss at the plasma membrane [159]. In support 
of this, reducing plasma membrane sphingomyelin improves systemic insulin sensitivity in sphingomyelin synthase 2 knockout mice [201]. Notably, the metabolic benefits are achieved when ceramide levels are increased in peripheral tissues [201]. Opposing to this, CERT improves insulin signaling under lipotoxic stress via decreasing ceramide levels both in vivo and in vitro [156], and ceramide has been well characterized as an inhibitor of Akt signaling [233,234]. Thus, the enhanced EGF-induced Akt signaling upon CERT deficiency [159] and improved insulin sensitivity upon sphingomyelin synthase 2 knockout mice [201] might be attributable to changes in other lipid factors. Indeed, the former study also found a decreased level of cholesterol at the plasma membrane, and the latter one observed a decreased level of circulating FFAs, both relating to Akt signaling.

Based on the current understanding, CERT exerts its functions in cancer primarily through the regulation of ceramide and sphingomyelin. Relative to bioactive ceramide, sphingomyelins mainly serve as building bricks in the cellular membrane and are required for cell growth and proliferation. Sphingomyelin level is difficult to change as drastically as ceramide in cells exposed to insults. This may explain why CERT exhibits a more consistent pro-cancer effect under chemotherapy, as CERT function may be more critical in alleviating the reinforced ceramide accumulation elicited by drug-induced stress. In the absence of chemotherapies, the balance between ceramide and sphingomyelin would be more important to cancer cell biology. However, the cellular functions of sphingomyelin in cancers have not been completely elucidated. Meanwhile, whether the effects of other lipid changes overwhelm the impacts of sphingomyelin and ceramide in specific cancer types remains elusive. Therefore, the differential CERT expression in human cancer cohorts should be further investigated from the following angles, including the stratification of the clinical samples, the CERT studies in primary cancer models, an in-depth understanding of the biological functions of sphingomyelin and a complete overview of lipidome and transcriptome in different cancer contexts.

\section{Conclusions}

Since the identification of the ceramide transport function of CERT by Hanada et al. in 2003, there have been extensive efforts to explore the molecular information, biological functions and human disease relevance of this protein over the past two decades. This is because it directly regulates the balance between sphingomyelin, the most abundant sphingolipid within the cell, and ceramide, the most well-characterized signaling sphingolipid. The structure-function relationship underlying the CERT-mediated ceramide transport from the ER to the trans-Golgi has been largely elucidated. This core function of CERT is dependent on its PH domain (Golgi targeting), START domain (ceramide binding) and FFAT motif (ER targeting), and it is tightly regulated by serial phosphorylation in the SRM. The crystal structure of functional domains in CERT has been resolved, which provides precise mechanistic insights. However, the knowledge in the regulation of CERT is currently limited to its post-translational modification. The changes in CERT mRNA levels have been observed in a few human cancers, but how CERT is regulated at the transcriptional level warrants further investigations. At the cellular level, CERT has been implicated in a number of biological functions at a variety of subcellular organelles, including the ER, mitochondria, the nucleus, the Golgi and the plasma membrane. CERT deficiency impairs some essential cellular functions and triggers cell death. Of more importance, the essentiality of CERT is convincingly seen in CERT knockout mice that die at the embryonic stage. Those ceramide-associated cellular impacts of CERT are better understood by virtue of our understanding of ceramide. In contrast, we lack knowledge in the biochemical and biophysical properties of sphingomyelin, which, if improved, can broaden the boundary of the CERT research. Meanwhile, ceramide with different lengths of fatty acyl chains exhibits distinct tissue distribution and cell type-specific biological functions [235-237], which might result in differential roles of CERT in different cancer cells. CERT may indirectly regulate other types of lipids, relating to cancer outcomes. An in-depth understanding of this can facilitate us better interpret CERT's roles in different 
human cancers. In addition, it is intriguing to know if short-form CERT exerts any biological functions via protein-protein interaction, independent of its lipid transport function. The complete loss of CERT leads to embryonic death, which is presumably the reason for the lack of in vivo studies on the role of CERT in cancer. This overlooked research topic should be investigated using inducible or cell type-specific knockout mice in the future. According to the existing analyses in human cancer samples, a differential expression pattern of CERT is found in different human cancers. Particularly, inconsistent expression levels are seen in breast and ovarian cancers, in which CERT level is downregulated in pooled subjects but upregulated in chemotherapy-resistant patients (Figure 5). Although these are analyzed in different cohorts, they still suggest CERT might play distinct roles in different stages or sub-types of cancers. Therefore, further analyses with human sample stratification and animal research in primary cancer models would contribute to depicting a clearer image of CERT in cancer. Lastly, as nearly all cancer-related CERT functions derive from its regulation of ceramide and sphingomyelin. With a new insight provided by the CERT research, we propose if the ratio between these two lipids is a determinant of cancer development and a predictor of cancer prognosis. In support of this, sphingolipid enzymes, such as sphingomyelin synthases, sphingomyelinases and ceramidases, that can regulate this ratio are all implicated in cancer. With the exponentially increasing applications of lipidomics, this could be answered in the near future. In addition, we should continue to interrogate if CERT expression is binarily correlated to cancer incidence. Following the notion that the ratio of $\beta$-amyloid 40 and 42 more accurately diagnoses Alzheimer's disease, the ratio of CERT to other paired factors may better predict cancer development and prognosis.

In summary, CERT might be a critical factor in cancers. Further investigations into CERT and its related ceramide and sphingomyelin will help to understand the fundamental aspects of cancer biology and identify novel druggable targets for the prevention and treatment of cancer.

Author Contributions: Y.Q. and L.H.C. conceived and wrote the manuscript. D.L. generated figures. X.T.L. contributed to gathering the literature. All authors have read and agreed to the published version of the manuscript.

Funding: This work was supported by the Project Grant (GNT1162545, QI) and Ideas Grant (GNT2002660, QI) from National Health and Medical Research Council, Australia, NSW Cardiovascular EMCR Grant by NSW Health, Australia (G205977, QI) and Future Leader Fellowship by Centenary Institute of Cancer Medicine and Cell Biology, Australia (QI).

Institutional Review Board Statement: Not applicable.

Informed Consent Statement: Not applicable.

Conflicts of Interest: The authors declare no conflict of interest.

\section{References}

1. Pan, C.; Li, B.; Simon, M.C. Moonlighting functions of metabolic enzymes and metabolites in cancer. Mol. Cell 2021, 81, 3760-3774. [CrossRef]

2. Broadfield, L.A.; Pane, A.A.; Talebi, A.; Swinnen, J.V.; Fendt, S.-M. Lipid metabolism in cancer: New perspectives and emerging mechanisms. Dev. Cell 2021, 56, 1363-1393. [CrossRef]

3. Qi, Y.; Wang, W.; Song, Z.; Aji, G.; Liu, X.T.; Xia, P. Role of Sphingosine Kinase in Type 2 Diabetes Mellitus. Front. Endocrinol. 2021, 11, 627076. [CrossRef] [PubMed]

4. Yoon, H.; Shaw, J.L.; Haigis, M.C.; Greka, A. Lipid metabolism in sickness and in health: Emerging regulators of lipotoxicity. Mol. Cell 2021, 81, 3708-3730. [CrossRef] [PubMed]

5. Snaebjornsson, M.T.; Janaki-Raman, S.; Schulze, A. Greasing the Wheels of the Cancer Machine: The Role of Lipid Metabolism in Cancer. Cell Metab. 2020, 31, 62-76. [CrossRef]

6. $\quad$ Butler, L.M.; Perone, Y.; Dehairs, J.; Lupien, L.E.; de Laat, V.; Talebi, A.; Loda, M.; Kinlaw, W.B.; Swinnen, J.V. Lipids and cancer: Emerging roles in pathogenesis, diagnosis and therapeutic intervention. Adv. Drug Deliv. Rev. 2020, 159, 245-293. [CrossRef] 
7. Garate, J.; Maimó-Barceló, A.; Bestard-Escalas, J.; Fernández, R.; Pérez-Romero, K.; Martínez, M.A.; Payeras, M.A.; Lopez, D.H.; Fernández, J.A.; Barceló-Coblijn, G. A Drastic Shift in Lipid Adducts in Colon Cancer Detected by MALDI-IMS Exposes Alterations in Specific K+ Channels. Cancers 2021, 13, 1350. [CrossRef] [PubMed]

8. Agarwala, P.K.; Aneja, R.; Kapoor, S. Lipidomic landscape in cancer: Actionable insights for membrane-based therapy and diagnoses. Med. Res. Rev. 2021, 31, 21868. [CrossRef]

9. Meikle, T.G.; Huynh, K.; Giles, C.; Meikle, P.J. Clinical Lipidomics: Realizing the potential of lipid profiling. J. Lipid Res. 2021, 62, 100127. [CrossRef]

10. Fahy, E.; Subramaniam, S.; Murphy, R.C.; Nishijima, M.; Raetz, C.R.H.; Shimizu, T.; Spener, F.; van Meer, G.; Wakelam, M.J.O.; Dennis, E.A. Update of the LIPID MAPS comprehensive classification system for lipids. J. Lipid Res. 2009, 50, S9-S14. [CrossRef]

11. Schömel, N.; Geisslinger, G.; Wegner, M.S. Influence of glycosphingolipids on cancer cell energy metabolism. Prog. Lipid Res. 2020, 79, 101050. [CrossRef] [PubMed]

12. Canals, D.; Clarke, C.J. Compartmentalization of Sphingolipid metabolism: Implications for signaling and therapy. Pharmacol. Ther. 2021, 15, 108005. [CrossRef]

13. Ogretmen, B. Sphingolipid metabolism in cancer signalling and therapy. Nat. Rev. Cancer 2018, 18, 33-50. [CrossRef]

14. Hannun, Y.A.; Obeid, L.M. Sphingolipids and their metabolism in physiology and disease. Nat. Rev. Mol. Cell Biol. 2018, 19, 175-191. [CrossRef]

15. Maceyka, M.; Spiegel, S. Sphingolipid metabolites in inflammatory disease. Nature 2014, 510, 58-67. [CrossRef]

16. Green, C.D.; Maceyka, M.; Cowart, L.A.; Spiegel, S. Sphingolipids in metabolic disease: The good, the bad, and the unknown Cell Metab. 2021, 33, 1293-1306. [CrossRef] [PubMed]

17. Trapika, I.; Liu, X.T.; Chung, L.H.; Lai, F.; Xie, C.; Zhao, Y.; Cui, S.; Chen, J.; Tran, C.; Wang, Q.; et al. Ceramide Regulates AntiTumor Mechanisms of Erianin in Androgen-Sensitive and Castration-Resistant Prostate Cancers. Front. Oncol. 2021, 11, 738078. [CrossRef] [PubMed]

18. Chen, J.; Wang, W.; Qi, Y.; Kaczorowski, D.; McCaughan, G.W.; Gamble, J.R.; Don, A.S.; Gao, X.; Vadas, M.A.; Xia, P. Deletion of sphingosine kinase 1 ameliorates hepatic steatosis in diet-induced obese mice: Role of PPARgamma. Biochim. Biophys. Acta 2016, 1861, 138-147. [CrossRef]

19. Morad, S.A.; Cabot, M.C. Ceramide-orchestrated signalling in cancer cells. Nat. Rev. Cancer 2013, 13, 51-65. [CrossRef]

20. Bai, A.P.; Guo, Y. Ceramide is a Potential Activator of Immune Responses Against Tumors. Gastroenterology 2018, 155, 579-580. [CrossRef]

21. Tallima, H.; Azzazy, H.M.E.; El Ridi, R. Cell surface sphingomyelin: Key role in cancer initiation, progression, and immune evasion. Lipids Health Dis. 2021, 20, 150. [CrossRef]

22. Taniguchi, M.; Okazaki, T. Role of ceramide/sphingomyelin (SM) balance regulated through "SM cycle" in cancer. Cell. Signal. 2021, 87, 110119. [CrossRef]

23. Osawa, Y.; Suetsugu, A.; Matsushima-Nishiwaki, R.; Yasuda, I.; Saibara, T.; Moriwaki, H.; Seishima, M.; Kozawa, O. Liver acid sphingomyelinase inhibits growth of metastatic colon cancer. J. Clin. Investig. 2013, 123, 834-843. [CrossRef] [PubMed]

24. Lin, M.; Liao, W.; Dong, M.; Zhu, R.; Xiao, J.; Sun, T.; Chen, Z.; Wu, B.; Jin, J. Exosomal neutral sphingomyelinase 1 suppresses hepatocellular carcinoma via decreasing the ratio of sphingomyelin/ceramide. FEBS J. 2018, 285, 3835-3848. [CrossRef]

25. Zhong, L.; Kong, J.N.; Dinkins, M.B.; Leanhart, S.; Zhu, Z.; Spassieva, S.D.; Qin, H.; Lin, H.P.; Elsherbini, A.; Wang, R.; et al. Increased liver tumor formation in neutral sphingomyelinase-2-deficient mice. J. Lipid Res. 2018, 59, 795-804. [CrossRef]

26. Mondal, S.; Mandal, C.; Sangwan, R.; Chandra, S.; Mandal, C. Withanolide D induces apoptosis in leukemia by targeting the activation of neutral sphingomyelinase-ceramide cascade mediated by synergistic activation of c-Jun N-terminal kinase and p38 mitogen-activated protein kinase. Mol. Cancer 2010, 9, 239. [CrossRef]

27. Montfort, A.; Bertrand, F.; Rochotte, J.; Gilhodes, J.; Filleron, T.; Milhès, J.; Dufau, C.; Imbert, C.; Riond, J.; Tosolini, M.; et al. Neutral Sphingomyelinase 2 Heightens Anti-Melanoma Immune Responses and Anti-PD-1 Therapy Efficacy. Cancer Immunol. Res. 2021, 9, 568-582. [CrossRef]

28. Ohnishi, T.; Hashizume, C.; Taniguchi, M.; Furumoto, H.; Han, J.; Gao, R.; Kinami, S.; Kosaka, T.; Okazaki, T. Sphingomyelin synthase 2 deficiency inhibits the induction of murine colitis-associated colon cancer. FASEB J. 2017, 31, 3816-3830. [CrossRef]

29. Zheng, K.; Chen, Z.; Feng, H.; Chen, Y.; Zhang, C.; Yu, J.; Luo, Y.; Zhao, L.; Jiang, X.; Shi, F. Sphingomyelin synthase 2 promotes an aggressive breast cancer phenotype by disrupting the homoeostasis of ceramide and sphingomyelin. Cell Death Dis. 2019, 10, 157. [CrossRef] [PubMed]

30. Burns, T.A.; Subathra, M.; Signorelli, P.; Choi, Y.; Yang, X.; Wang, Y.; Villani, M.; Bhalla, K.; Zhou, D.; Luberto, C. Sphingomyelin synthase 1 activity is regulated by the BCR-ABL oncogene[S]. J. Lipid Res. 2013, 54, 794-805. [CrossRef] [PubMed]

31. Barceló-Coblijn, G.; Martin, M.L.; de Almeida, R.F.M.; Noguera-Salvà, M.A.; Marcilla-Etxenike, A.; Guardiola-Serrano, F.; Lüth, A.; Kleuser, B.; Halver, J.E.; Escribá, P.V. Sphingomyelin and sphingomyelin synthase (SMS) in the malignant transformation of glioma cells and in 2-hydroxyoleic acid therapy. Proc. Natl. Acad. Sci. USA 2011, 108, 19569. [CrossRef] [PubMed]

32. Moorthi, S.; Burns, T.A.; Yu, G.Q.; Luberto, C. Bcr-Abl regulation of sphingomyelin synthase 1 reveals a novel oncogenic-driven mechanism of protein up-regulation. FASEB J. 2018, 32, 4270-4283. [CrossRef] [PubMed]

33. Fukasawa, M.; Nishijima, M.; Hanada, K. Genetic evidence for ATP-dependent endoplasmic reticulum-to-Golgi apparatus trafficking of ceramide for sphingomyelin synthesis in Chinese hamster ovary cells. J. Cell Biol. 1999, 144, 673-685. [CrossRef] [PubMed] 
34. Hanada, K.; Kumagai, K.; Yasuda, S.; Miura, Y.; Kawano, M.; Fukasawa, M.; Nishijima, M. Molecular machinery for non-vesicular trafficking of ceramide. Nature 2003, 426, 803-809. [CrossRef]

35. Scheffer, L.; Raghavendra, P.R.; Ma, J.; Acharya, J.K. Ceramide transfer protein and cancer. Anti-Cancer Agents Med. Chem. 2011, 11, 904-910. [CrossRef]

36. Carreira, A.C.; Santos, T.C.; Lone, M.A.; Zupančič, E.; Lloyd-Evans, E.; de Almeida, R.F.M.; Hornemann, T.; Silva, L.C. Mammalian sphingoid bases: Biophysical, physiological and pathological properties. Prog. Lipid Res. 2019, 75, 100988. [CrossRef]

37. Marquês, J.T.; Marinho, H.S.; de Almeida, R.F.M. Sphingolipid hydroxylation in mammals, yeast and plants-An integrated view. Prog. Lipid Res. 2018, 71, 18-42. [CrossRef]

38. Thudichum, J.L.W. A Treatise on the Chemical Constitution of the Brain: Based throughout upon Original Researches; Bailliere, Tindall, and Cox: London, UK, 1884.

39. Merrill, A.H. Sphingolipid and Glycosphingolipid Metabolic Pathways in the Era of Sphingolipidomics. Chem. Rev. 2011, 111, 6387-6422. [CrossRef] [PubMed]

40. Carter, H.E.; Haines, W.J.; Ledyard, W.E.; Norris, W.P. Biochemistry of the sphingolipides; preparation of sphingolipides from beef brain and spinal cord. J. Biol. Chem. 1947, 169, 77-82. [CrossRef]

41. Sud, M.; Fahy, E.; Cotter, D.; Brown, A.; Dennis, E.A.; Glass, C.K.; Merrill, A.H., Jr.; Murphy, R.C.; Raetz, C.R.H.; Russell, D.W.; et al. LMSD: LIPID MAPS structure database. Nucleic Acids Res. 2007, 35, D527-D532. [CrossRef]

42. Fahy, E.; Sud, M.; Cotter, D.; Subramaniam, S. LIPID MAPS online tools for lipid research. Nucleic Acids Res. 2007, 35, W606-W612. [CrossRef]

43. Stoffel, W. Studies on the biosynthesis and degradation of sphingosine bases. Chem. Phys. Lipids 1970, 5, 139-158. [CrossRef]

44. Merrill, A.H., Jr. Characterization of serine palmitoyltransferase activity in Chinese hamster ovary cells. Biochim. Biophys. Acta 1983, 754, 284-291. [CrossRef]

45. Mandon, E.C.; Ehses, I.; Rother, J.; van Echten, G.; Sandhoff, K. Subcellular localization and membrane topology of serine palmitoyltransferase, 3-dehydrosphinganine reductase, and sphinganine $\mathrm{N}$-acyltransferase in mouse liver. J. Biol. Chem. 1992, 267, 11144-11148. [PubMed]

46. Nagiec, M.M.; Baltisberger, J.A.; Wells, G.B.; Lester, R.L.; Dickson, R.C. The LCB2 gene of Saccharomyces and the related LCB1 gene encode subunits of serine palmitoyltransferase, the initial enzyme in sphingolipid synthesis. Proc. Natl. Acad. Sci. USA 1994, 91, 7899-7902. [CrossRef]

47. Weiss, B.; Stoffel, W. Human and murine serine-palmitoyl-CoA transferase-cloning, expression and characterization of the key enzyme in sphingolipid synthesis. Eur. J. Biochem. 1997, 249, 239-247. [CrossRef] [PubMed]

48. Hornemann, T.; Richard, S.; Rütti, M.F.; Wei, Y.; von Eckardstein, A. Cloning and initial characterization of a new subunit for mammalian serine-palmitoyltransferase. J. Biol. Chem. 2006, 281, 37275-37281. [CrossRef]

49. Han, G.; Gupta, S.D.; Gable, K.; Niranjanakumari, S.; Moitra, P.; Eichler, F.; Brown, R.H.; Harmon, J.M.; Dunn, T.M. Identification of small subunits of mammalian serine palmitoyltransferase that confer distinct acyl-CoA substrate specificities. Proc. Natl. Acad. Sci. USA 2009, 106, 8186. [CrossRef] [PubMed]

50. Kihara, A.; Igarashi, Y. FVT-1 is a mammalian 3-ketodihydrosphingosine reductase with an active site that faces the cytosolic side of the endoplasmic reticulum membrane. J. Biol. Chem. 2004, 279, 49243-49250. [CrossRef]

51. D'Mello, N.P.; Childress, A.M.; Franklin, D.S.; Kale, S.P.; Pinswasdi, C.; Jazwinski, S.M. Cloning and characterization of LAG1, a longevity-assurance gene in yeast. J. Biol. Chem. 1994, 269, 15451-15459. [CrossRef]

52. Venkataraman, K.; Riebeling, C.; Bodennec, J.; Riezman, H.; Allegood, J.C.; Sullards, M.C.; Merrill, A.H., Jr.; Futerman, A.H. Upstream of growth and differentiation factor 1 (uog1), a mammalian homolog of the yeast longevity assurance gene 1 (LAG1), regulates N-stearoyl-sphinganine (C18-(dihydro)ceramide) synthesis in a fumonisin B1-independent manner in mammalian cells. J. Biol. Chem. 2002, 277, 35642-35649. [CrossRef]

53. Ternes, P.; Franke, S.; Zähringer, U.; Sperling, P.; Heinz, E. Identification and characterization of a sphingolipid delta 4-desaturase family. J. Biol. Chem. 2002, 277, 25512-25518. [CrossRef]

54. Beauchamp, E.; Goenaga, D.; Le Bloc'h, J.; Catheline, D.; Legrand, P.; Rioux, V. Myristic acid increases the activity of dihydroceramide Delta4-desaturase 1 through its N-terminal myristoylation. Biochimie 2007, 89, 1553-1561. [CrossRef]

55. Levy, M.; Futerman, A.H. Mammalian ceramide synthases. IUBMB Life 2010, 62, 347-356. [CrossRef]

56. Turpin-Nolan, S.M.; Brüning, J.C. The role of ceramides in metabolic disorders: When size and localization matters. Nat. Rev. Endocrinol. 2020, 16, 224-233. [CrossRef]

57. Gatt, S. Enzymic Hydrolysis and Synthesis of Ceramides. J. Biol. Chem. 1963, 238, 3131-3133. [CrossRef]

58. Bernardo, K.; Hurwitz, R.; Zenk, T.; Desnick, R.J.; Ferlinz, K.; Schuchman, E.H.; Sandhoff, K. Purification, characterization, and biosynthesis of human acid ceramidase. J. Biol. Chem. 1995, 270, 11098-11102. [CrossRef]

59. Ito, M.; Okino, N.; Tani, M. New insight into the structure, reaction mechanism, and biological functions of neutral ceramidase. Biochim. Biophys. Acta (BBA) Mol. Cell. Biol. Lipids 2014, 1841, 682-691. [CrossRef]

60. Hernández-Corbacho, M.J.; Salama, M.F.; Canals, D.; Senkal, C.E.; Obeid, L.M. Sphingolipids in mitochondria. Biochim. Biophys. Acta Mol. Cell. Biol. Lipids 2017, 1862, 56-68. [CrossRef] [PubMed]

61. Sun, W.; Xu, R.; Hu, W.; Jin, J.; Crellin, H.A.; Bielawski, J.; Szulc, Z.M.; Thiers, B.H.; Obeid, L.M.; Mao, C. Upregulation of the human alkaline ceramidase 1 and acid ceramidase mediates calcium-induced differentiation of epidermal keratinocytes. J. Investig. Dermatol. 2008, 128, 389-397. [CrossRef] [PubMed] 
62. Xu, R.; Sun, W.; Jin, J.; Obeid, L.M.; Mao, C. Role of alkaline ceramidases in the generation of sphingosine and its phosphate in erythrocytes. FASEB J. 2010, 24, 2507-2515. [CrossRef] [PubMed]

63. Xu, R.; Jin, J.; Hu, W.; Sun, W.; Bielawski, J.; Szulc, Z.; Taha, T.; Obeid, L.M.; Mao, C. Golgi alkaline ceramidase regulates cell proliferation and survival by controlling levels of sphingosine and S1P. FASEB J. 2006, 20, 1813-1825. [CrossRef] [PubMed]

64. Sun, W.; Hu, W.; Xu, R.; Jin, J.; Szulc, Z.M.; Zhang, G.; Galadari, S.H.; Obeid, L.M.; Mao, C. Alkaline ceramidase 2 regulates beta1 integrin maturation and cell adhesion. FASEB J. 2009, 23, 656-666. [CrossRef]

65. Hu, W.; Xu, R.; Sun, W.; Szulc, Z.M.; Bielawski, J.; Obeid, L.M.; Mao, C. Alkaline ceramidase 3 (ACER3) hydrolyzes unsaturated long-chain ceramides, and its down-regulation inhibits both cell proliferation and apoptosis. J. Biol. Chem. 2010, 285, 7964-7976. [CrossRef]

66. Yamaji, T.; Hanada, K. Sphingolipid metabolism and interorganellar transport: Localization of sphingolipid enzymes and lipid transfer proteins. Traffic 2015, 16, 101-122. [CrossRef]

67. Kohama, T.; Olivera, A.; Edsall, L.; Nagiec, M.M.; Dickson, R.; Spiegel, S. Molecular cloning and functional characterization of murine sphingosine kinase. J. Biol. Chem. 1998, 273, 23722-23728. [CrossRef] [PubMed]

68. Liu, Y.Y.; Han, T.Y.; Giuliano, A.E.; Hansen, N.; Cabot, M.C. Uncoupling ceramide glycosylation by transfection of glucosylceramide synthase antisense reverses adriamycin resistance. J. Biol. Chem. 2000, 275, 7138-7143. [CrossRef] [PubMed]

69. Saba, J.D.; Nara, F.; Bielawska, A.; Garrett, S.; Hannun, Y.A. The BST1 gene of Saccharomyces cerevisiae is the sphingosine-1phosphate lyase. J. Biol. Chem. 1997, 272, 26087-26090. [CrossRef]

70. Alvarez, S.E.; Harikumar, K.B.; Hait, N.C.; Allegood, J.; Strub, G.M.; Kim, E.Y.; Maceyka, M.; Jiang, H.; Luo, C.; Kordula, T.; et al. Sphingosine-1-phosphate is a missing cofactor for the E3 ubiquitin ligase TRAF2. Nature 2010, 465, 1084-1088. [CrossRef] [PubMed]

71. Xia, P.; Wang, L.; Moretti, P.A.; Albanese, N.; Chai, F.; Pitson, S.M.; D’Andrea, R.J.; Gamble, J.R.; Vadas, M.A. Sphingosine kinase interacts with TRAF2 and dissects tumor necrosis factor-alpha signaling. J. Biol. Chem. 2002, 277, 7996-8003. [CrossRef]

72. Hait, N.C.; Allegood, J.; Maceyka, M.; Strub, G.M.; Harikumar, K.B.; Singh, S.K.; Luo, C.; Marmorstein, R.; Kordula, T.; Milstien, S.; et al. Regulation of histone acetylation in the nucleus by sphingosine-1-phosphate. Science 2009, 325, 1254-1257. [CrossRef] [PubMed]

73. Strub, G.M.; Paillard, M.; Liang, J.; Gomez, L.; Allegood, J.C.; Hait, N.C.; Maceyka, M.; Price, M.M.; Chen, Q.; Simpson, D.C.; et al. Sphingosine-1-phosphate produced by sphingosine kinase 2 in mitochondria interacts with prohibitin 2 to regulate complex IV assembly and respiration. FASEB J. 2011, 25, 600-612. [CrossRef] [PubMed]

74. Maceyka, M.; Sankala, H.; Hait, N.C.; Le Stunff, H.; Liu, H.; Toman, R.; Collier, C.; Zhang, M.; Satin, L.S.; Merrill, A.H., Jr.; et al. SphK1 and SphK2, sphingosine kinase isoenzymes with opposing functions in sphingolipid metabolism. J. Biol. Chem. 2005, 280, 37118-37129. [CrossRef] [PubMed]

75. Qi, Y.; Wang, W.; Chen, J.; Dai, L.; Kaczorowski, D.; Gao, X.; Xia, P. Sphingosine Kinase 1 Protects Hepatocytes from Lipotoxicity via Down-regulation of IRE1 $\alpha$ Protein Expression. J. Biol. Chem. 2015, 290, 23282-23290. [CrossRef]

76. Van Veldhoven, P.P.; Mannaerts, G.P. Subcellular localization and membrane topology of sphingosine-1-phosphate lyase in rat liver. J. Biol. Chem. 1991, 266, 12502-12507. [CrossRef]

77. Ikeda, M.; Kihara, A.; Igarashi, Y. Sphingosine-1-phosphate lyase SPL is an endoplasmic reticulum-resident, integral membrane protein with the pyridoxal 5'-phosphate binding domain exposed to the cytosol. Biochem. Biophys. Res. Commun. 2004, 325, 338-343. [CrossRef]

78. Reiss, U.; Oskouian, B.; Zhou, J.; Gupta, V.; Sooriyakumaran, P.; Kelly, S.; Wang, E.; Merrill, A.H., Jr.; Saba, J.D. Sphingosinephosphate lyase enhances stress-induced ceramide generation and apoptosis. J. Biol. Chem. 2004, 279, 1281-1290. [CrossRef]

79. Allende, M.L.; Sasaki, T.; Kawai, H.; Olivera, A.; Mi, Y.; van Echten-Deckert, G.; Hajdu, R.; Rosenbach, M.; Keohane, C.A.; Mandala, S.; et al. Mice deficient in sphingosine kinase 1 are rendered lymphopenic by FTY720. J. Biol. Chem. 2004, 279, 52487-52492. [CrossRef]

80. Zheng, X.; Li, W.; Ren, L.; Liu, J.; Pang, X.; Chen, X.; Kang, D.; Wang, J.; Du, G. The sphingosine kinase-1/sphingosine-1-phosphate axis in cancer: Potential target for anticancer therapy. Pharmacol. Ther. 2019, 195, 85-99. [CrossRef]

81. Aji, G.; Huang, Y.; Ng, M.L.; Wang, W.; Lan, T.; Li, M.; Li, Y.; Chen, Q.; Li, R.; Yan, S.; et al. Regulation of hepatic insulin signaling and glucose homeostasis by sphingosine kinase 2. Proc. Natl. Acad. Sci. USA 2020, 117, 24434. [CrossRef]

82. Gomez, L.; Paillard, M.; Price, M.; Chen, Q.; Teixeira, G.; Spiegel, S.; Lesnefsky, E.J. A novel role for mitochondrial sphingosine-1phosphate produced by sphingosine kinase-2 in PTP-mediated cell survival during cardioprotection. Basic Res. Cardiol. 2011, 106, 1341-1353. [CrossRef] [PubMed]

83. Bektas, M.; Allende, M.L.; Lee, B.G.; Chen, W.; Amar, M.J.; Remaley, A.T.; Saba, J.D.; Proia, R.L. Sphingosine 1-Phosphate Lyase Deficiency Disrupts Lipid Homeostasis in Liver. J. Biol. Chem. 2010, 285, 10880-10889. [CrossRef] [PubMed]

84. Mizugishi, K.; Yamashita, T.; Olivera, A.; Miller, G.F.; Spiegel, S.; Proia, R.L. Essential role for sphingosine kinases in neural and vascular development. Mol. Cell. Biol. 2005, 25, 11113-11121. [CrossRef]

85. Schmahl, J.; Raymond, C.S.; Soriano, P. PDGF signaling specificity is mediated through multiple immediate early genes. Nat. Genet. 2007, 39, 52-60. [CrossRef]

86. Bajjalieh, S.M.; Martin, T.F.; Floor, E. Synaptic vesicle ceramide kinase. A calcium-stimulated lipid kinase that co-purifies with brain synaptic vesicles. J. Biol. Chem. 1989, 264, 14354-14360. [CrossRef] 
87. Huitema, K.; van den Dikkenberg, J.; Brouwers, J.F.; Holthuis, J.C. Identification of a family of animal sphingomyelin synthases. EMBO J. 2004, 23, 33-44. [CrossRef]

88. Vacaru, A.M.; Tafesse, F.G.; Ternes, P.; Kondylis, V.; Hermansson, M.; Brouwers, J.F.H.M.; Somerharju, P.; Rabouille, C.; Holthuis, J.C.M. Sphingomyelin synthase-related protein SMSr controls ceramide homeostasis in the ER. J. Cell Biol. 2009, 185, 1013-1027. [CrossRef]

89. Basu, S.; Kaufman, B.; Roseman, S. Enzymatic synthesis of ceramide-glucose and ceramide-lactose by glycosyltransferases from embryonic chicken brain. J. Biol. Chem. 1968, 243, 5802-5804. [CrossRef]

90. Senkal, C.E.; Salama, M.F.; Snider, A.J.; Allopenna, J.J.; Rana, N.A.; Koller, A.; Hannun, Y.A.; Obeid, L.M. Ceramide Is Metabolized to Acylceramide and Stored in Lipid Droplets. Cell Metab. 2017, 25, 686-697. [CrossRef]

91. van den Hill, A.; van Heusden, G.P.; Wirtz, K.W. The synthesis of sphingomyelin in the Morris hepatomas 7777 and $5123 \mathrm{D}$ is restricted to the plasma membrane. Biochim. Biophys. Acta 1985, 833, 354-357. [CrossRef]

92. Jeckel, D.; Karrenbauer, A.; Birk, R.; Richard Schmidt, R.; Wieland, F. Sphingomyelin is synthesized in the cis Golgi. FEBS Lett. 1990, 261, 155-157. [CrossRef]

93. Futerman, A.H.; Stieger, B.; Hubbard, A.L.; Pagano, R.E. Sphingomyelin synthesis in rat liver occurs predominantly at the cis and medial cisternae of the Golgi apparatus. J. Biol. Chem. 1990, 265, 8650-8657. [CrossRef]

94. D'Angelo, G.; Moorthi, S.; Luberto, C. Chapter Three-Role and Function of Sphingomyelin Biosynthesis in the Development of Cancer. In Advances in Cancer Research; Chalfant, C.E., Fisher, P.B., Eds.; Academic Press: Cambridge, MA, USA, 2018; pp. 61-96.

95. Deevska, G.M.; Dotson, P.P.; Karakashian, A.A.; Isaac, G.; Wrona, M.; Kelly, S.B.; Merrill, A.H.; Nikolova-Karakashian, M.N. Novel Interconnections in Lipid Metabolism Revealed by Overexpression of Sphingomyelin Synthase-1. J. Biol. Chem. 2017, 292, 5110-5122. [CrossRef] [PubMed]

96. Halter, D.; Neumann, S.; van Dijk, S.M.; Wolthoorn, J.; de Mazière, A.M.; Vieira, O.V.; Mattjus, P.; Klumperman, J.; van Meer, G.; Sprong, H. Pre- and post-Golgi translocation of glucosylceramide in glycosphingolipid synthesis. J. Cell Biol. 2007, 179, 101-115. [CrossRef] [PubMed]

97. Tafesse, F.G.; Huitema, K.; Hermansson, M.; van der Poel, S.; van den Dikkenberg, J.; Uphoff, A.; Somerharju, P.; Holthuis, J.C.M. Both Sphingomyelin Synthases SMS1 and SMS2 Are Required for Sphingomyelin Homeostasis and Growth in Human HeLa Cells*. J. Biol. Chem. 2007, 282, 17537-17547. [CrossRef] [PubMed]

98. Quintern, L.E.; Weitz, G.; Nehrkorn, H.; Tager, J.M.; Schram, A.W.; Sandhoff, K. Acid sphingomyelinase from human urine: Purification and characterization. Biochim. Biophys. Acta 1987, 922, 323-336. [CrossRef]

99. Schuchman, E.H.; Levran, O.; Pereira, L.V.; Desnick, R.J. Structural organization and complete nucleotide sequence of the gene encoding human acid sphingomyelinase (SMPD1). Genomics 1992, 12, 197-205. [CrossRef]

100. Jenkins, R.W.; Clarke, C.J.; Canals, D.; Snider, A.J.; Gault, C.R.; Heffernan-Stroud, L.; Wu, B.X.; Simbari, F.; Roddy, P.; Kitatani, K.; et al. Regulation of CC ligand 5/RANTES by acid sphingomyelinase and acid ceramidase. J. Biol. Chem. 2011, 286, 13292-13303. [CrossRef]

101. Schissel, S.L.; Keesler, G.A.; Schuchman, E.H.; Williams, K.J.; Tabas, I. The cellular trafficking and zinc dependence of secretory and lysosomal sphingomyelinase, two products of the acid sphingomyelinase gene. J. Biol. Chem. 1998, 273, 18250-18259. [CrossRef] [PubMed]

102. Ferlinz, K.; Hurwitz, R.; Vielhaber, G.; Suzuki, K.; Sandhoff, K. Occurrence of two molecular forms of human acid sphingomyelinase. Biochem. J. 1994, 301, 855-862. [CrossRef]

103. Schissel, S.L.; Jiang, X.; Tweedie-Hardman, J.; Jeong, T.; Camejo, E.H.; Najib, J.; Rapp, J.H.; Williams, K.J.; Tabas, I. Secretory sphingomyelinase, a product of the acid sphingomyelinase gene, can hydrolyze atherogenic lipoproteins at neutral $\mathrm{pH}$. Implications for atherosclerotic lesion development. J. Biol. Chem. 1998, 273, 2738-2746. [CrossRef]

104. Rhein, C.; Reichel, M.; Mühle, C.; Rotter, A.; Schwab, S.G.; Kornhuber, J. Secretion of Acid Sphingomyelinase is Affected by its Polymorphic Signal Peptide. Cell. Physiol. Biochem. 2014, 34, 1385-1401. [CrossRef] [PubMed]

105. Tomiuk, S.; Zumbansen, M.; Stoffel, W. Characterization and subcellular localization of murine and human magnesium-dependent neutral sphingomyelinase. J. Biol. Chem. 2000, 275, 5710-5717. [CrossRef] [PubMed]

106. Mizutani, Y.; Tamiya-Koizumi, K.; Nakamura, N.; Kobayashi, M.; Hirabayashi, Y.; Yoshida, S. Nuclear localization of neutral sphingomyelinase 1: Biochemical and immunocytochemical analyses. J. Cell Sci. 2001, 114, 3727-3736. [CrossRef]

107. Hofmann, K.; Tomiuk, S.; Wolff, G.; Stoffel, W. Cloning and characterization of the mammalian brain-specific, $\mathrm{Mg}^{2+}$-dependent neutral sphingomyelinase. Proc. Natl. Acad. Sci. USA 2000, 97, 5895.

108. Milhas, D.; Clarke, C.J.; Idkowiak-Baldys, J.; Canals, D.; Hannun, Y.A. Anterograde and retrograde transport of neutral sphingomyelinase-2 between the Golgi and the plasma membrane. Biochim. Biophys. Acta 2010, 1801, 1361-1374. [CrossRef]

109. Krut, O.; Wiegmann, K.; Kashkar, H.; Yazdanpanah, B.; Krönke, M. Novel tumor necrosis factor-responsive mammalian neutral sphingomyelinase-3 is a C-tail-anchored protein. J. Biol. Chem. 2006, 281, 13784-13793. [CrossRef]

110. Wu, B.X.; Rajagopalan, V.; Roddy, P.L.; Clarke, C.J.; Hannun, Y.A. Identification and characterization of murine mitochondriaassociated neutral sphingomyelinase (MA-nSMase), the mammalian sphingomyelin phosphodiesterase 5. J. Biol. Chem. 2010, 285, 17993-18002. [CrossRef] [PubMed]

111. Duan, R.D.; Cheng, Y.; Hansen, G.; Hertervig, E.; Liu, J.J.; Syk, I.; Sjostrom, H.; Nilsson, A. Purification, localization, and expression of human intestinal alkaline sphingomyelinase. J. Lipid Res. 2003, 44, 1241-1250. [CrossRef] [PubMed] 
112. Duan, R.-D. Alkaline sphingomyelinase: An old enzyme with novel implications. Biochim. Biophys. Acta 2006, 1761, $281-291$. [CrossRef]

113. Pettus, B.J.; Bielawski, J.; Porcelli, A.M.; Reames, D.L.; Johnson, K.R.; Morrow, J.; Chalfant, C.E.; Obeid, L.M.; Hannun, Y.A. The sphingosine kinase 1/sphingosine-1-phosphate pathway mediates COX-2 induction and PGE2 production in response to TNF-alpha. FASEB J. 2003, 17, 1411-1421. [CrossRef]

114. Pettus, B.J.; Bielawska, A.; Subramanian, P.; Wijesinghe, D.S.; Maceyka, M.; Leslie, C.C.; Evans, J.H.; Freiberg, J.; Roddy, P.; Hannun, Y.A.; et al. Ceramide 1-phosphate is a direct activator of cytosolic phospholipase A2. J. Biol. Chem. 2004, 279, 11320-11326. [CrossRef] [PubMed]

115. Lamour, N.F.; Stahelin, R.V.; Wijesinghe, D.S.; Maceyka, M.; Wang, E.; Allegood, J.C.; Merrill, A.H., Jr.; Cho, W.; Chalfant, C.E. Ceramide kinase uses ceramide provided by ceramide transport protein: Localization to organelles of eicosanoid synthesis. J Lipid Res. 2007, 48, 1293-1304. [CrossRef] [PubMed]

116. Boudker, O.; Futerman, A.H. Detection and characterization of ceramide-1-phosphate phosphatase activity in rat liver plasma membrane. J. Biol. Chem. 1993, 268, 22150-22155. [CrossRef]

117. Sprong, H.; Kruithof, B.; Leijendekker, R.; Slot, J.W.; van Meer, G.; van der Sluijs, P. UDP-galactose:ceramide galactosyltransferase is a class I integral membrane protein of the endoplasmic reticulum. J. Biol. Chem. 1998, 273, 25880-25888. [CrossRef]

118. Futerman, A.H.; Pagano, R.E. Determination of the intracellular sites and topology of glucosylceramide synthesis in rat liver. Biochem. J. 1991, 280, 295-302. [CrossRef]

119. Yaghootfam, A.; Sorkalla, T.; Häberlein, H.; Gieselmann, V.; Kappler, J.; Eckhardt, M. Cerebroside sulfotransferase forms homodimers in living cells. Biochemistry 2007, 46, 9260-9269. [CrossRef]

120. Uemura, S.; Shishido, F.; Kashimura, M.; Inokuchi, J. The regulation of ER export and Golgi retention of ST3Gal5 (GM3/GM4 synthase) and B4GalNAcT1 (GM2/GD2/GA2 synthase) by arginine/lysine-based motif adjacent to the transmembrane domain. Glycobiology 2015, 25, 1410-1422. [CrossRef] [PubMed]

121. Liu, Y.-Y.; Hill, R.A.; Li, Y.-T. Chapter Three-Ceramide Glycosylation Catalyzed by Glucosylceramide Synthase and Cancer Drug Resistance. In Advances in Cancer Research; Norris, J.S., Ed.; Academic Press: Cambridge, MA, USA, 2013 ; pp. 59-89.

122. Brady, R.O.; Kanfer, J.N.; Bradley, R.M.; Shapiro, D. Demonstration of a deficiency of glucocerebroside-cleaving enzyme in Gaucher's disease. J. Clin. Investig. 1966, 45, 1112-1115. [CrossRef]

123. Kobayashi, T.; Shinnoh, N.; Goto, I.; Kuroiwa, Y. Hydrolysis of galactosylceramide is catalyzed by two genetically distinct acid beta-galactosidases. J. Biol. Chem. 1985, 260, 14982-14987. [CrossRef]

124. Okabe, H.; Kishimoto, Y. In vivo metabolism of ceramides in rat brain. Fatty acid replacement and esterification of ceramide. J. Biol. Chem. 1977, 252, 7068-7073. [CrossRef]

125. Deng, Y.; Rivera-Molina, F.E.; Toomre, D.K.; Burd, C.G. Sphingomyelin is sorted at the trans Golgi network into a distinct class of secretory vesicle. Proc. Natl. Acad. Sci. USA 2016, 113, 6677.

126. Hussain, M.M.; Jin, W.; Jiang, X.C. Mechanisms involved in cellular ceramide homeostasis. Nutr. Metab. 2012, 9, 71. [CrossRef]

127. Simanshu, D.K.; Kamlekar, R.K.; Wijesinghe, D.S.; Zou, X.; Zhai, X.; Mishra, S.K.; Molotkovsky, J.G.; Malinina, L.; Hinchcliffe, E.H.; Chalfant, C.E.; et al. Non-vesicular trafficking by a ceramide-1-phosphate transfer protein regulates eicosanoids. Nature 2013, 500, 463-467. [CrossRef] [PubMed]

128. D’Angelo, G.; Polishchuk, E.; Di Tullio, G.; Santoro, M.; Di Campli, A.; Godi, A.; West, G.; Bielawski, J.; Chuang, C.C.; van der Spoel, A.C.; et al. Glycosphingolipid synthesis requires FAPP2 transfer of glucosylceramide. Nature 2007, $449,62-67$. [CrossRef]

129. Kjellberg, M.A.; Backman, A.P.E.; Ohvo-Rekilä, H.; Mattjus, P. Alternation in the Glycolipid Transfer Protein Expression Causes Changes in the Cellular Lipidome. PLoS ONE 2014, 9, e97263. [CrossRef] [PubMed]

130. Giussani, P.; Colleoni, T.; Brioschi, L.; Bassi, R.; Hanada, K.; Tettamanti, G.; Riboni, L.; Viani, P. Ceramide traffic in C6 glioma cells: Evidence for CERT-dependent and independent transport from ER to the Golgi apparatus. Biochim. Biophys. Acta 2008, 1781, 40-51. [CrossRef]

131. Raya, A.; Revert-Ros, F.; Martinez-Martinez, P.; Navarro, S.; Rosello, E.; Vieites, B.; Granero, F.; Forteza, J.; Saus, J. Goodpasture antigen-binding protein, the kinase that phosphorylates the goodpasture antigen, is an alternatively spliced variant implicated in autoimmune pathogenesis. J. Biol. Chem. 2000, 275, 40392-40399. [CrossRef] [PubMed]

132. Revert, F.; Ventura, I.; Martínez-Martínez, P.; Granero-Moltó, F.; Revert-Ros, F.; Macías, J.; Saus, J. Goodpasture antigen-binding protein is a soluble exportable protein that interacts with type IV collagen. Identification of novel membrane-bound isoforms J. Biol. Chem. 2008, 283, 30246-30255. [CrossRef] [PubMed]

133. Raya, A.; Revert, F.; Navarro, S.; Saus, J. Characterization of a Novel Type of Serine/Threonine Kinase That Specifically Phosphorylates the Human Goodpasture Antigen. J. Biol. Chem. 1999, 274, 12642-12649. [CrossRef]

134. Kumagai, K.; Hanada, K. Structure, functions and regulation of CERT, a lipid-transfer protein for the delivery of ceramide at the ER-Golgi membrane contact sites. FEBS Lett. 2019, 593, 2366-2377. [CrossRef]

135. Alpy, F.; Tomasetto, C. Give lipids a START: The StAR-related lipid transfer (START) domain in mammals. J. Cell Sci. 2005, 118, 2791-2801. [CrossRef]

136. Kudo, N.; Kumagai, K.; Tomishige, N.; Yamaji, T.; Wakatsuki, S.; Nishijima, M.; Hanada, K.; Kato, R. Structural basis for specific lipid recognition by CERT responsible for nonvesicular trafficking of ceramide. Proc. Natl. Acad. Sci. USA 2008, 105, 488. [CrossRef] 
137. Kudo, N.; Kumagai, K.; Matsubara, R.; Kobayashi, S.; Hanada, K.; Wakatsuki, S.; Kato, R. Crystal Structures of the CERT START Domain with Inhibitors Provide Insights into the Mechanism of Ceramide Transfer. J. Mol. Biol. 2010, 396, 245-251. [CrossRef]

138. Kumagai, K.; Yasuda, S.; Okemoto, K.; Nishijima, M.; Kobayashi, S.; Hanada, K. CERT mediates intermembrane transfer of various molecular species of ceramides. J. Biol. Chem. 2005, 280, 6488-6495. [CrossRef]

139. Shaner, R.L.; Allegood, J.C.; Park, H.; Wang, E.; Kelly, S.; Haynes, C.A.; Sullards, M.C.; Merrill, A.H., Jr. Quantitative analysis of sphingolipids for lipidomics using triple quadrupole and quadrupole linear ion trap mass spectrometers. J. Lipid Res. 2009, 50, 1692-1707. [CrossRef] [PubMed]

140. Sugiki, T.; Takeuchi, K.; Yamaji, T.; Takano, T.; Tokunaga, Y.; Kumagai, K.; Hanada, K.; Takahashi, H.; Shimada, I. Structural basis for the Golgi association by the pleckstrin homology domain of the ceramide trafficking protein (CERT). J. Biol. Chem. 2012, 287, 33706-33718. [CrossRef]

141. Kawano, M.; Kumagai, K.; Nishijima, M.; Hanada, K. Efficient trafficking of ceramide from the endoplasmic reticulum to the Golgi apparatus requires a VAMP-associated protein-interacting FFAT motif of CERT. J. Biol. Chem. 2006, 281, 30279-30288. [CrossRef]

142. Lomasney, J.W.; Cheng, H.F.; Wang, L.P.; Kuan, Y.; Liu, S.; Fesik, S.W.; King, K. Phosphatidylinositol 4,5-bisphosphate binding to the pleckstrin homology domain of phospholipase C-delta1 enhances enzyme activity. J. Biol. Chem. 1996, 271, 25316-25326. [CrossRef]

143. Milburn, C.C.; Deak, M.; Kelly, S.M.; Price, N.C.; Alessi, D.R.; Van Aalten, D.M. Binding of phosphatidylinositol 3,4,5trisphosphate to the pleckstrin homology domain of protein kinase B induces a conformational change. Biochem. J. 2003, 375, 531-538. [CrossRef]

144. Mesmin, B.; Bigay, J.; Moser von Filseck, J.; Lacas-Gervais, S.; Drin, G.; Antonny, B. A four-step cycle driven by PI(4)P hydrolysis directs sterol/PI(4)P exchange by the ER-Golgi tether OSBP. Cell 2013, 155, 830-843. [CrossRef]

145. Schu, P.V.; Takegawa, K.; Fry, M.J.; Stack, J.H.; Waterfield, M.D.; Emr, S.D. Phosphatidylinositol 3-kinase encoded by yeast VPS34 gene essential for protein sorting. Science 1993, 260, 88-91. [CrossRef]

146. De Matteis, M.A.; D'Angelo, G. The role of the phosphoinositides at the Golgi complex. Biochem. Soc. Symp. 2007, 74, 107-116.

147. Stahelin, R.V.; Karathanassis, D.; Murray, D.; Williams, R.L.; Cho, W. Structural and membrane binding analysis of the Phox homology domain of Bem1p: Basis of phosphatidylinositol 4-phosphate specificity. J. Biol. Chem. 2007, 282, 25737-25747. [CrossRef] [PubMed]

148. Tóth, B.; Balla, A.; Ma, H.; Knight, Z.A.; Shokat, K.M.; Balla, T. Phosphatidylinositol 4-kinase IIIbeta regulates the transport of ceramide between the endoplasmic reticulum and Golgi. J. Biol. Chem. 2006, 281, 36369-36377. [CrossRef]

149. Prashek, J.; Truong, T.; Yao, X. Crystal Structure of the Pleckstrin Homology Domain from the Ceramide Transfer Protein: Implications for Conformational Change upon Ligand Binding. PLoS ONE 2013, 8, e79590.

150. Prashek, J.; Bouyain, S.; Fu, M.; Li, Y.; Berkes, D.; Yao, X. Interaction between the PH and START domains of ceramide transfer protein competes with phosphatidylinositol 4-phosphate binding by the PH domain. J. Biol. Chem. 2017, 292, 14217-14228. [CrossRef]

151. Loewen, C.J.R.; Levine, T.P. A Highly Conserved Binding Site in Vesicle-associated Membrane Protein-associated Protein (VAP) for the FFAT Motif of Lipid-binding Proteins. J. Biol. Chem. 2005, 280, 14097-14104. [CrossRef]

152. Loewen, C.J.R.; Roy, A.; Levine, T.P. A conserved ER targeting motif in three families of lipid binding proteins and in Opilp binds VAP. EMBO J. 2003, 22, 2025-2035. [CrossRef]

153. Wyles, J.P.; McMaster, C.R.; Ridgway, N.D. Vesicle-associated membrane protein-associated protein-A (VAP-A) interacts with the oxysterol-binding protein to modify export from the endoplasmic reticulum. J. Biol. Chem. 2002, 277, 29908-29918. [CrossRef]

154. Granero-Moltó, F.; Sarmah, S.; O’Rear, L.; Spagnoli, A.; Abrahamson, D.; Saus, J.; Hudson, B.G.; Knapik, E.W. Goodpasture antigen-binding protein and its spliced variant, ceramide transfer protein, have different functions in the modulation of apoptosis during zebrafish development. J. Biol. Chem. 2008, 283, 20495-20504. [CrossRef]

155. Lee, A.J.X.; Roylance, R.; Sander, J.; Gorman, P.; Endesfelder, D.; Kschischo, M.; Jones, N.P.; East, P.; Nicke, B.; Spassieva, S.; et al. CERT depletion predicts chemotherapy benefit and mediates cytotoxic and polyploid-specific cancer cell death through autophagy induction. J. Pathol. 2012, 226, 482-494. [CrossRef]

156. Bandet, C.L.; Mahfouz, R.; Véret, J.; Sotiropoulos, A.; Poirier, M.; Giussani, P.; Campana, M.; Philippe, E.; Blachnio-Zabielska, A.; Ballaire, R.; et al. Ceramide Transporter CERT Is Involved in Muscle Insulin Signaling Defects Under Lipotoxic Conditions. Diabetes 2018, 67, 1258. [CrossRef]

157. Ishibashi, Y.; Kohyama-Koganeya, A.; Hirabayashi, Y. New insights on glucosylated lipids: Metabolism and functions. Biochim. Biophys. Acta (BBA) Mol. Cell Biol. Lipids 2013, 1831, 1475-1485. [CrossRef]

158. Rao, R.P.; Yuan, C.; Allegood, J.C.; Rawat, S.S.; Edwards, M.B.; Wang, X.; Merrill, A.H., Jr.; Acharya, U.; Acharya, J.K. Ceramide transfer protein function is essential for normal oxidative stress response and lifespan. Proc. Natl. Acad. Sci. USA 2007, 104, 11364-11369. [CrossRef]

159. Heering, J.; Weis, N.; Holeiter, M.; Neugart, F.; Staebler, A.; Fehm, T.N.; Bischoff, A.; Schiller, J.; Duss, S.; Schmid, S.; et al. Loss of the ceramide transfer protein augments EGF receptor signaling in breast cancer. Cancer Res. 2012, 72, 2855-2866. [CrossRef]

160. Wang, X.; Rao, R.P.; Kosakowska-Cholody, T.; Masood, M.A.; Southon, E.; Zhang, H.; Berthet, C.; Nagashim, K.; Veenstra, T.K.; Tessarollo, L.; et al. Mitochondrial degeneration and not apoptosis is the primary cause of embryonic lethality in ceramide transfer protein mutant mice. J. Cell Biol. 2009, 184, 143-158. [CrossRef] 
161. Rao, R.P.; Scheffer, L.; Srideshikan, S.M.; Parthibane, V.; Kosakowska-Cholody, T.; Masood, M.A.; Nagashima, K.; Gudla, P.; Lockett, S.; Acharya, U.; et al. Ceramide transfer protein deficiency compromises organelle function and leads to senescence in primary cells. PLOS ONE 2014, 9, e92142.

162. Crivelli, S.M.; Luo, Q.; Stevens, J.A.A.; Giovagnoni, C.; van Kruining, D.; Bode, G.; den Hoedt, S.; Hobo, B.; Scheithauer, A.L.; Walter, J.; et al. CERT(L) reduces $\mathrm{C} 16$ ceramide, amyloid- $\beta$ levels, and inflammation in a model of Alzheimer's disease. Alzheimers Res. Ther. 2021, 13, 45. [CrossRef]

163. Kumagai, K.; Kawano, M.; Shinkai-Ouchi, F.; Nishijima, M.; Hanada, K. Interorganelle trafficking of ceramide is regulated by phosphorylation-dependent cooperativity between the PH and START domains of CERT. J. Biol. Chem. 2007, 282, 17758-17766. [CrossRef]

164. Fugmann, T.; Hausser, A.; Schöffler, P.; Schmid, S.; Pfizenmaier, K.; Olayioye, M.A. Regulation of secretory transport by protein kinase D-mediated phosphorylation of the ceramide transfer protein. J. Cell Biol. 2007, 178, 15-22. [CrossRef]

165. Tomishige, N.; Kumagai, K.; Kusuda, J.; Nishijima, M.; Hanada, K. Casein kinase I\{gamma\}2 down-regulates trafficking of ceramide in the synthesis of sphingomyelin. Mol. Biol. Cell 2009, 20, 348-357. [CrossRef]

166. Kumagai, K.; Kawano-Kawada, M.; Hanada, K. Phosphoregulation of the ceramide transport protein CERT at serine 315 in the interaction with VAMP-associated protein (VAP) for inter-organelle trafficking of ceramide in mammalian cells. J. Biol. Chem. 2014, 289, 10748-10760. [CrossRef] [PubMed]

167. Weber, P.; Hornjik, M.; Olayioye, M.A.; Hausser, A.; Radde, N.E. A computational model of PKD and CERT interactions at the trans-Golgi network of mammalian cells. BMC Syst. Biol. 2015, 9, 9. [CrossRef]

168. Tamura, N.; Sakai, S.; Martorell, L.; Colomé, R.; Mizuike, A.; Goto, A.; Ortigoza-Escobar, J.D.; Hanada, K. Intellectual disabilityassociated mutations in the ceramide transport protein gene CERT1 lead to aberrant function and subcellular distribution. J. Biol. Chem. 2021, 297, 101338. [CrossRef] [PubMed]

169. Sugiki, T.; Egawa, D.; Kumagai, K.; Kojima, C.; Fujiwara, T.; Takeuchi, K.; Shimada, I.; Hanada, K.; Takahashi, H. Phosphoinositide binding by the $\mathrm{PH}$ domain in ceramide transfer protein (CERT) is inhibited by hyperphosphorylation of an adjacent serine-repeat motif. J. Biol. Chem. 2018, 293, 11206-11217. [CrossRef] [PubMed]

170. Saito, S.; Matsui, H.; Kawano, M.; Kumagai, K.; Tomishige, N.; Hanada, K.; Echigo, S.; Tamura, S.; Kobayashi, T. Protein phosphatase 2Cepsilon is an endoplasmic reticulum integral membrane protein that dephosphorylates the ceramide transport protein CERT to enhance its association with organelle membranes. J. Biol. Chem. 2008, 283, 6584-6593. [CrossRef]

171. Loizides-Mangold, U.; David, F.P.A.; Nesatyy, V.J.; Kinoshita, T.; Riezman, H. Glycosylphosphatidylinositol anchors regulate glycosphingolipid levels. J. Lipid Res. 2012, 53, 1522-1534. [CrossRef] [PubMed]

172. Perry, R.J.; Ridgway, N.D. Molecular mechanisms and regulation of ceramide transport. Biochim. Biophys. Acta 2005, 1734, 220-234. [CrossRef]

173. Goto, A.; Charman, M.; Ridgway, N.D. Oxysterol-binding Protein Activation at Endoplasmic Reticulum-Golgi Contact Sites Reorganizes Phosphatidylinositol 4-Phosphate Pools. J. Biol. Chem. 2016, 291, 1336-1347. [CrossRef]

174. Banerji, S.; Ngo, M.; Lane, C.F.; Robinson, C.-A.; Minogue, S.; Ridgway, N.D. Oxysterol binding protein-dependent activation of sphingomyelin synthesis in the golgi apparatus requires phosphatidylinositol 4-kinase II $\alpha$. Mol. Biol. Cell 2010, 21, 4141-4150. [CrossRef]

175. Capasso, S.; Sticco, L.; Rizzo, R.; Pirozzi, M.; Russo, D.; Dathan, N.A.; Campelo, F.; van Galen, J.; Hölttä-Vuori, M.; Turacchio, G.; et al. Sphingolipid metabolic flow controls phosphoinositide turnover at the trans-Golgi network. EMBO J. 2017, 36, 1736-1754. [CrossRef]

176. Tuuf, J.; Kjellberg, M.A.; Molotkovsky, J.G.; Hanada, K.; Mattjus, P. The intermembrane ceramide transport catalyzed by CERT is sensitive to the lipid environment. Biochim. Biophys. Acta (BBA) Biomembr. 2011, 1808, 229-235. [CrossRef]

177. Chandran, S.; Machamer, C.E. Inactivation of ceramide transfer protein during pro-apoptotic stress by Golgi disassembly and caspase cleavage. Biochem. J. 2012, 442, 391-401. [CrossRef]

178. Hanada, K. Co-evolution of sphingomyelin and the ceramide transport protein CERT. Biochim. Biophys. Acta 2014, 1841, 704-719. [CrossRef]

179. Simons, K.; Ikonen, E. Functional rafts in cell membranes. Nature 1997, 387, 569-572. [CrossRef]

180. Pralle, A.; Keller, P.; Florin, E.L.; Simons, K.; Hörber, J.K. Sphingolipid-cholesterol rafts diffuse as small entities in the plasma membrane of mammalian cells. J. Cell Biol. 2000, 148, 997-1008. [CrossRef]

181. Cheng, Z.J.; Singh, R.D.; Sharma, D.K.; Holicky, E.L.; Hanada, K.; Marks, D.L.; Pagano, R.E. Distinct mechanisms of clathrinindependent endocytosis have unique sphingolipid requirements. Mol. Biol. Cell 2006, 17, 3197-3210. [CrossRef]

182. Zama, K.; Mitsutake, S.; Okazaki, T.; Igarashi, Y. Sphingomyelin in microdomains of the plasma membrane regulates amino acid-stimulated mTOR signal activation. Cell Biol. Int. 2018, 42, 823-831. [CrossRef]

183. Todor, I.N.; Lukyanova, N.Y.; Chekhun, V.F. The lipid content of cisplatin- and doxorubicin-resistant MCF-7 human breast cancer cells. Exp. Oncol. 2012, 34, 97-100.

184. Shakor, A.B.A.; Taniguchi, M.; Kitatani, K.; Hashimoto, M.; Asano, S.; Hayashi, A.; Nomura, K.; Bielawski, J.; Bielawska, A.; Watanabe, K.; et al. Sphingomyelin synthase 1-generated sphingomyelin plays an important role in transferrin trafficking and cell proliferation. J. Biol. Chem. 2011, 286, 36053-36062. [CrossRef]

185. Wesley, U.V.; Hatcher, J.F.; Dempsey, R.J. Sphingomyelin Synthase 1 Regulates Neuro-2a Cell Proliferation and Cell Cycle Progression Through Modulation of p27 Expression and Akt Signaling. Mol. Neurobiol. 2015, 51, 1530-1541. [CrossRef] [PubMed] 
186. Hanada, K.; Nishijima, M.; Kiso, M.; Hasegawa, A.; Fujita, S.; Ogawa, T.; Akamatsu, Y. Sphingolipids are essential for the growth of Chinese hamster ovary cells. Restoration of the growth of a mutant defective in sphingoid base biosynthesis by exogenous sphingolipids. J. Biol. Chem. 1992, 267, 23527-23533. [CrossRef]

187. Asano, S.; Kitatani, K.; Taniguchi, M.; Hashimoto, M.; Zama, K.; Mitsutake, S.; Igarashi, Y.; Takeya, H.; Kigawa, J.; Hayashi, A.; et al. Regulation of cell migration by sphingomyelin synthases: Sphingomyelin in lipid rafts decreases responsiveness to signaling by the CXCL12/CXCR4 pathway. Mol. Cell. Biol. 2012, 32, 3242-3252. [CrossRef]

188. Hannun, Y.A.; Obeid, L.M. Principles of bioactive lipid signalling: Lessons from sphingolipids. Nat. Rev. Mol. Cell Biol. 2008, 9 , 139-150. [CrossRef]

189. Lahiri, S.; Futerman, A.H. The metabolism and function of sphingolipids and glycosphingolipids. Cell. Mol. Life Sci. 2007, 64, 2270-2284. [CrossRef]

190. Smyth, M.J.; Obeid, L.M.; Hannun, Y.A. Ceramide: A novel lipid mediator of apoptosis. Adv. Pharmacol. 1997, 41, 133-154.

191. Mencarelli, C.; Bode, G.H.; Losen, M.; Kulharia, M.; Molenaar, P.C.; Veerhuis, R.; Steinbusch, H.W.; De Baets, M.H.; Nicolaes, G.A.; Martinez-Martinez, P. Goodpasture antigen-binding protein/ceramide transporter binds to human serum amyloid P-component and is present in brain amyloid plaques. J. Biol. Chem. 2012, 287, 14897-14911. [CrossRef] [PubMed]

192. Bode, G.H.; Losen, M.; Buurman, W.A.; Veerhuis, R.; Molenaar, P.C.; Steinbusch, H.W.M.; De Baets, M.H.; Daha, M.R.; Martinez-Martinez, P. Complement Activation by Ceramide Transporter Proteins. J. Immunol. 2014, 192, 1154. [CrossRef]

193. Jain, A.; Beutel, O.; Ebell, K.; Korneev, S.; Holthuis, J.C.M. Diverting CERT-mediated ceramide transport to mitochondria triggers Bax-dependent apoptosis. J. Cell Sci. 2017, 130, 360-371. [CrossRef]

194. Jain, A.; Dadsena, S.; Holthuis, J.C.M. A switchable ceramide transfer protein for dissecting the mechanism of ceramide-induced mitochondrial apoptosis. FEBS Lett. 2020, 594, 3739-3750. [CrossRef] [PubMed]

195. Swanton, C.; Marani, M.; Pardo, O.; Warne, P.H.; Kelly, G.; Sahai, E.; Elustondo, F.; Chang, J.; Temple, J.; Ahmed, A.A.; et al. Regulators of mitotic arrest and ceramide metabolism are determinants of sensitivity to paclitaxel and other chemotherapeutic drugs. Cancer Cell 2007, 11, 498-512. [CrossRef] [PubMed]

196. Palau, V.E.; Chakraborty, K.; Wann, D.; Lightner, J.; Hilton, K.; Brannon, M.; Stone, W.; Krishnan, K. $\gamma$-Tocotrienol induces apoptosis in pancreatic cancer cells by upregulation of ceramide synthesis and modulation of sphingolipid transport. BMC Cancer 2018, 18, 564. [CrossRef]

197. Hullin-Matsuda, F.; Tomishige, N.; Sakai, S.; Ishitsuka, R.; Ishii, K.; Makino, A.; Greimel, P.; Abe, M.; Laviad, E.L.; Lagarde, M.; et al. Limonoid compounds inhibit sphingomyelin biosynthesis by preventing CERT protein-dependent extraction of ceramides from the endoplasmic reticulum. J. Biol. Chem. 2012, 287, 24397-24411. [CrossRef]

198. Uddin, S.J.; Nahar, L.; Shilpi, J.A.; Shoeb, M.; Borkowski, T.; Gibbons, S.; Middleton, M.; Byres, M.; Sarker, S.D. Gedunin, a limonoid from Xylocarpus granatum, inhibits the growth of CaCo-2 colon cancer cell line in vitro. Phytother. Res. 2007, 21, 757-761. [CrossRef] [PubMed]

199. Charruyer, A.; Bell, S.M.; Kawano, M.; Douangpanya, S.; Yen, T.Y.; Macher, B.A.; Kumagai, K.; Hanada, K.; Holleran, W.M.; Uchida, Y. Decreased ceramide transport protein (CERT) function alters sphingomyelin production following UVB irradiation. J. Biol. Chem. 2008, 283, 16682-16692. [CrossRef]

200. Kujjo, L.L.; Perez, G.I. Ceramide and mitochondrial function in aging oocytes: Joggling a new hypothesis and old players. Reproduction 2012, 143, 1-10. [CrossRef] [PubMed]

201. Li, Z.; Zhang, H.; Liu, J.; Liang, C.-P.; Li, Y.; Li, Y.; Teitelman, G.; Beyer, T.; Bui Hai, H.; Peake, D.A.; et al. Reducing Plasma Membrane Sphingomyelin Increases Insulin Sensitivity. Mol. Cell. Biol. 2011, 31, 4205-4218. [CrossRef]

202. Garcia-Ruiz, C.; Colell, A.; Mari, M.; Morales, A.; Fernandez-Checa, J.C. Direct effect of ceramide on the mitochondrial electron transport chain leads to generation of reactive oxygen species. Role of mitochondrial glutathione. J. Biol. Chem. 1997, 272, 11369-11377. [CrossRef]

203. Quillet-Mary, A.; Jaffrezou, J.P.; Mansat, V.; Bordier, C.; Naval, J.; Laurent, G. Implication of mitochondrial hydrogen peroxide generation in ceramide-induced apoptosis. J. Biol. Chem. 1997, 272, 21388-21395. [CrossRef]

204. Degli Esposti, M.; McLennan, H. Mitochondria and cells produce reactive oxygen species in virtual anaerobiosis: Relevance to ceramide-induced apoptosis. FEBS Lett. 1998, 430, 338-342. [CrossRef]

205. Gudz, T.I.; Tserng, K.Y.; Hoppel, C.L. Direct inhibition of mitochondrial respiratory chain complex III by cell-permeable ceramide. J. Biol. Chem. 1997, 272, 24154-24158. [CrossRef]

206. Zigdon, H.; Kogot-Levin, A.; Park, J.W.; Goldschmidt, R.; Kelly, S.; Merrill, A.H., Jr.; Scherz, A.; Pewzner-Jung, Y.; Saada, A.; Futerman, A.H. Ablation of ceramide synthase 2 causes chronic oxidative stress due to disruption of the mitochondrial respiratory chain. J. Biol. Chem. 2013, 288, 4947-4956. [CrossRef] [PubMed]

207. Fajardo, V.A.; McMeekin, L.; LeBlanc, P.J. Influence of phospholipid species on membrane fluidity: A meta-analysis for a novel phospholipid fluidity index. J. Membr. Biol. 2011, 244, 97-103. [CrossRef]

208. Sergent, O.; Pereira, M.; Belhomme, C.; Chevanne, M.; Huc, L.; Lagadic-Gossmann, D. Role for membrane fluidity in ethanolinduced oxidative stress of primary rat hepatocytes. J. Pharmacol. Exp. Ther. 2005, 313, 104-111. [CrossRef]

209. Tu, R.; Yang, W.; Hu, Z. Inhibition of sphingomyelin synthase 1 affects ceramide accumulation and hydrogen peroxide-induced apoptosis in Neuro-2a cells. Neuroreport 2016, 27, 967-973. [CrossRef]

210. Ramming, T.; Hansen, H.G.; Nagata, K.; Ellgaard, L.; Appenzeller-Herzog, C. GPx8 peroxidase prevents leakage of H2O2 from the endoplasmic reticulum. Free Radic. Biol. Med. 2014, 70, 106-116. [CrossRef] 
211. Bosello Travain, V.; Miotto, G.; Vuckovic, A.M.; Cozza, G.; Roveri, A.; Toppo, S.; Ursini, F.; Venerando, R.; Zaccarin, M.; Maiorino, M. Lack of glutathione peroxidase-8 in the ER impacts on lipid composition of HeLa cells microsomal membranes. Free Radic. Biol. Med. 2020, 147, 80-89. [CrossRef] [PubMed]

212. Rysman, E.; Brusselmans, K.; Scheys, K.; Timmermans, L.; Derua, R.; Munck, S.; Van Veldhoven, P.P.; Waltregny, D.; Daniels, V.W.; Machiels, J.; et al. De novo lipogenesis protects cancer cells from free radicals and chemotherapeutics by promoting membrane lipid saturation. Cancer Res. 2010, 70, 8117-8126. [CrossRef]

213. Mencarelli, C.; Hammels, C.; Van Den Broeck, J.; Losen, M.; Steinbusch, H.; Revert, F.; Saus, J.; Hopkins, D.A.; De Baets, M.H.; Steinbusch, H.W.; et al. The expression of the Goodpasture antigen-binding protein (ceramide transporter) in adult rat brain. J. Chem. Neuroanat. 2009, 38, 97-105. [CrossRef]

214. Matarin, M.; Salih, D.A.; Yasvoina, M.; Cummings, D.M.; Guelfi, S.; Liu, W.; Nahaboo Solim, M.A.; Moens, T.G.; Paublete, R.M.; Ali, S.S.; et al. A genome-wide gene-expression analysis and database in transgenic mice during development of amyloid or tau pathology. Cell Rep. 2015, 10, 633-644. [CrossRef]

215. Xie, Z.; Hur, S.K.; Zhao, L.; Abrams, C.S.; Bankaitis, V.A. A Golgi Lipid Signaling Pathway Controls Apical Golgi Distribution and Cell Polarity during Neurogenesis. Dev. Cell 2018, 44, 725-740.e724. [CrossRef]

216. Derré, I.; Swiss, R.; Agaisse, H. The Lipid Transfer Protein CERT Interacts with the Chlamydia Inclusion Protein IncD and Participates to ER-Chlamydia Inclusion Membrane Contact Sites. PLOS Pathog. 2011, 7, e1002092. [CrossRef]

217. Tachida, Y.; Kumagai, K.; Sakai, S.; Ando, S.; Yamaji, T.; Hanada, K. Chlamydia trachomatis-infected human cells convert ceramide to sphingomyelin without sphingomyelin synthases 1 and 2. FEBS Lett. 2020, 594, 519-529. [CrossRef] [PubMed]

218. Kumagai, K.; Elwell, C.A.; Ando, S.; Engel, J.N.; Hanada, K. Both the N- and C-terminal regions of the Chlamydial inclusion protein $\mathrm{D}(\mathrm{InCD})$ are required for interaction with the pleckstrin homology domain of the ceramide transport protein CERT. Biochem. Biophys. Res. Commun. 2018, 505, 1070-1076. [CrossRef] [PubMed]

219. Elwell, C.A.; Jiang, S.; Kim, J.H.; Lee, A.; Wittmann, T.; Hanada, K.; Melancon, P.; Engel, J.N. Chlamydia trachomatis Co-opts GBF1 and CERT to Acquire Host Sphingomyelin for Distinct Roles during Intracellular Development. PLOS Pathog. 2011, 7, e1002198. [CrossRef]

220. Koch-Edelmann, S.; Banhart, S.; Saied, E.M.; Rose, L.; Aeberhard, L.; Laue, M.; Doellinger, J.; Arenz, C.; Heuer, D. The cellular ceramide transport protein CERT promotes Chlamydia psittaci infection and controls bacterial sphingolipid uptake. Cell Microbiol. 2017, 19, e12752. [CrossRef] [PubMed]

221. Amako, Y.; Syed, G.H.; Siddiqui, A. Protein kinase D negatively regulates hepatitis C virus secretion through phosphorylation of oxysterol-binding protein and ceramide transfer protein. J. Biol. Chem. 2011, 286, 11265-11274. [CrossRef]

222. Daha, M.R. Role of complement in innate immunity and infections. Crit. Rev. Immunol. 2010, 30, 47-52. [CrossRef]

223. Revert, F.; Merino, R.; Monteagudo, C.; Macias, J.; Peydró, A.; Alcácer, J.; Muniesa, P.; Marquina, R.; Blanco, M.; Iglesias, M.; et al. Increased Goodpasture Antigen-Binding Protein Expression Induces Type IV Collagen Disorganization and Deposit of Immunoglobulin A in Glomerular Basement Membrane. Am. J. Pathol. 2007, 171, 1419-1430. [CrossRef]

224. Juul, N.; Szallasi, Z.; Eklund, A.C.; Li, Q.; Burrell, R.A.; Gerlinger, M.; Valero, V.; Andreopoulou, E.; Esteva, F.J.; Symmans, W.F.; et al. Assessment of an RNA interference screen-derived mitotic and ceramide pathway metagene as a predictor of response to neoadjuvant paclitaxel for primary triple-negative breast cancer: A retrospective analysis of five clinical trials. Lancet Oncol. 2010, 11, 358-365. [CrossRef]

225. Hess, K.R.; Anderson, K.; Symmans, W.F.; Valero, V.; Ibrahim, N.; Mejia, J.A.; Booser, D.; Theriault, R.L.; Buzdar, A.U.; Dempsey, P.J.; et al. Pharmacogenomic predictor of sensitivity to preoperative chemotherapy with paclitaxel and fluorouracil, doxorubicin, and cyclophosphamide in breast cancer. J. Clin. Oncol. 2006, 24, 4236-4244. [CrossRef] [PubMed]

226. Györffy, B.; Lanczky, A.; Eklund, A.C.; Denkert, C.; Budczies, J.; Li, Q.; Szallasi, Z. An online survival analysis tool to rapidly assess the effect of 22,277 genes on breast cancer prognosis using microarray data of 1,809 patients. Breast Cancer Res. Treat. 2010, 123, 725-731. [CrossRef] [PubMed]

227. Tang, Z.; Li, C.; Kang, B.; Gao, G.; Li, C.; Zhang, Z. GEPIA: A web server for cancer and normal gene expression profiling and interactive analyses. Nucleic Acids Res. 2017, 45, W98-W102. [CrossRef]

228. Tang, Z.; Kang, B.; Li, C.; Chen, T.; Zhang, Z. GEPIA2: An enhanced web server for large-scale expression profiling and interactive analysis. Nucleic Acids Res. 2019, 47, W556-W560. [CrossRef] [PubMed]

229. Farmer, P.; Bonnefoi, H.; Becette, V.; Tubiana-Hulin, M.; Fumoleau, P.; Larsimont, D.; Macgrogan, G.; Bergh, J.; Cameron, D.; Goldstein, D.; et al. Identification of molecular apocrine breast tumours by microarray analysis. Oncogene 2005, 24, 4660-4671. [CrossRef]

230. Richardson, A.L.; Wang, Z.C.; De Nicolo, A.; Lu, X.; Brown, M.; Miron, A.; Liao, X.; Iglehart, J.D.; Livingston, D.M.; Ganesan, S. X chromosomal abnormalities in basal-like human breast cancer. Cancer Cell 2006, 9, 121-132. [CrossRef]

231. Pang, K.H.; Esperto, F.; Noon, A.P. Opportunities of next-generation sequencing in non-muscle invasive bladder cancer outcome prediction. Transl. Androl. Urol. 2017, 6, 1043-1048. [CrossRef] [PubMed]

232. Wang, M.; Zheng, S.; Li, X.; Ding, Y.; Zhang, M.; Lin, L.; Xu, H.; Cheng, Y.; Zhang, X.; Xu, H.; et al. Integrated Analysis of lncRNA-miRNA-mRNA ceRNA Network Identified lncRNA EPB41L4A-AS1 as a Potential Biomarker in Non-small Cell Lung Cancer. Front. Genet. 2020, 11, 1130. [CrossRef]

233. Summers, S.A.; Chaurasia, B.; Holland, W.L. Metabolic Messengers: Ceramides. Nat. Metab. 2019, 1, 1051-1058. [CrossRef] 
234. Chaurasia, B.; Summers, S.A. Ceramides in Metabolism: Key Lipotoxic Players. Annu. Rev. Physiol. 2021, 83, 303-330. [CrossRef] [PubMed]

235. Lee, H.; Rotolo, J.A.; Mesicek, J.; Penate-Medina, T.; Rimner, A.; Liao, W.C.; Yin, X.; Ragupathi, G.; Ehleiter, D.; Gulbins, E.; et al. Mitochondrial ceramide-rich macrodomains functionalize Bax upon irradiation. PLoS ONE 2011, 6, e19783. [CrossRef]

236. Sassa, T.; Suto, S.; Okayasu, Y.; Kihara, A. A shift in sphingolipid composition from C24 to C16 increases susceptibility to apoptosis in HeLa cells. Biochim. Biophys. Acta (BBA) Mol. Cell Biol. Lipids 2012, 1821, 1031-1037. [CrossRef]

237. Hartmann, D.; Lucks, J.; Fuchs, S.; Schiffmann, S.; Schreiber, Y.; Ferreirós, N.; Merkens, J.; Marschalek, R.; Geisslinger, G.; Grösch, S. Long chain ceramides and very long chain ceramides have opposite effects on human breast and colon cancer cell growth. Int. J. Biochem. Cell Biol. 2012, 44, 620-628. [CrossRef] 